\title{
Authentication as Institutional Maintenance Work
}

\author{
Colombero, Sylvain; Boxenbaum, Eva
}

Document Version

Accepted author manuscript

Published in:

Journal of Management Studies

DOI:

10.1111/joms.12413

Publication date:

2019

License

Unspecified

Citation for published version (APA):

Colombero, S., \& Boxenbaum, E. (2019). Authentication as Institutional Maintenance Work. Journal of Management Studies, 56(2), 408-440. https://doi.org/10.1111/joms.12413

Link to publication in CBS Research Portal

\section{General rights}

Copyright and moral rights for the publications made accessible in the public portal are retained by the authors and/or other copyright owners and it is a condition of accessing publications that users recognise and abide by the legal requirements associated with these rights.

Take down policy

If you believe that this document breaches copyright please contact us (research.lib@cbs.dk) providing details, and we will remove access to the work immediately and investigate your claim. 


\title{
Authentication as Institutional Maintenance Work Sylvain Colombero and Eva Boxenbaum
}

\author{
Journal article (Accepted manuscript*)
}

\section{Please cite this article as:}

Colombero, S., \& Boxenbaum, E. (2019). Authentication as Institutional Maintenance Work. Journal of Management Studies, 56(2), 408-440. https://doi.org/10.1111/joms.12413

This is the peer reviewed version of the article, which has been published in final form at DOI: https://doi.org/10.1111/joms.12413

This article may be used for non-commercial purposes in accordance with Wiley Terms and Conditions for Self-Archiving

* This version of the article has been accepted for publication and undergone full peer review but has not been through the copyediting, typesetting, pagination and proofreading process, which may lead to differences between this version and the publisher's final version AKA Version of Record.

Uploaded to CBS Research Portal: July २०19 


\title{
AUTHENTICATION AS INSTITUTIONAL MAINTENANCE WORK
}

\author{
Sylvain COLOMBERO \\ Grenoble Ecole de Management, \\ 12 rue Pierre Sémard, 38000 Grenoble, France \\ sylvain.colombero@grenoble-em.com \\ Phone: +33476706189 \\ $\&$ \\ Eva BOXENBAUM \\ Copenhagen Business School \\ Kilevej 14A, 2000 Frederiksberg, Denmark \\ eb.ioa@cbs.dk \\ $\&$ \\ MINES ParisTech - PSL Research University \\ 60, bd Saint-Michel, 75272 Paris Cedex 06, France
}

Accepted for publication in Journal of Management Studies

September 27, 2018 


\title{
AUTHENTICATION AS INSTITUTIONAL MAINTENANCE WORK
}

\begin{abstract}
Institutional maintenance work refers to actors' deliberate effort to maintain an institution. This paper examines how actors use authentication, i.e., the relational constitution of an artifact as original or as a genuine expression of a particular type, style or person, to accomplish institutional maintenance work. We investigated contemporary adjustments to six listed buildings. These works were undertaken to keep these buildings functional while at the same time protecting their listing; by doing so they contributed to maintain the institution of Architectural Heritage. Our analysis identifies three forms of authentication: Material Consolidation, Crafts Mobilization and Character Enhancement. We elaborate on each of them and explain their institutional underpinnings and outcomes. The paper concludes with an articulation of authentication as a potent form of institutional maintenance work. Taking its starting point in materiality, authentication is a relational practice that helps maintain institutions relying on irreplaceable artifacts for their maintenance.
\end{abstract}

Keywords: institutional maintenance, materiality, authenticity, architectural heritage.

Acknowledgments: We thank the editor, Gerardo Patriotta, and three anonymous reviewers for challenging and constructive feedbacks on prior versions of this article. We also express our gratitude to Roy Suddaby, as well as to Bernard Leca, Bryant Hudson, Julien Jourdan, Kristian Kreiner, François-Xavier de Vaujany, Aurélien Acquier, Guilhem Bascle, Davide Ravasi, Mia Raynard, Guiseppe Delmestri, Renate Meyer, Dennis Jancsary, and Markus Höllerer for their helpful advice during events at WU Vienna and the Paris Organization Theory Research Group (POTREG). We acknowledge financial support from the Danish Council for Independent Research - Social Sciences, project DFF - 1327-00030 and from Fondation Mines ParisTech. 


\section{INTRODUCTION}

Actors engage in institutional maintenance work when they deliberately seek to reproduce institutions through their daily activities (Lawrence \& Suddaby, 2006). Previous research has identified verbal discourse (Quinn-Trank \& Washington, 2009; Zilber, 2009) and practices (Dacin, Munir \& Tracey, 2010) as effective forms of institutional maintenance work. Recently, scholars have turned to artifacts as another potent resource for institutional maintenance work. An artifact is defined as "a discrete material object, consciously produced or transformed by human activity, under the influence of the physical and/or cultural environment" (Suchman, 2003, p. 98). Artifacts communicate institutional content through material means (Carlile, Nicolini, Langley \& Tsoukas, 2013; Dover \& Lawrence, 2010; Jones, Boxenbaum \& Anthony, 2013), a capacity that imbues them with an ability to influence institutional dynamics and contribute to institutional maintenance (Jones, Maoret, Massa \& Svejenova, 2012; Jones \& Massa, 2013; Lawrence, Leca \& Zilber, 2013). For instance, the classical Roman columns that often decorate court houses evoke, and reproduce, ancient Greek and Roman institutions of democracy and justice.

Artifacts have particular qualities that impact their capacity for institutional maintenance. We focus here on the quality of irreplaceability, understood as a widespread perception among a group of actors that a particular artifact carries value that significantly exceeds that of its reproduction or replacement. Artifacts are irreplaceable when they are widely perceived as authentic, that is, when they are "believed to be 'the original' or 'the real thing"" (Grayson \& Martinec, 2004, p. 297) or "being true to" something, that is, when actors construe them as "genuine", "original" or "true" (Carroll, 2015; Carroll \& Wheaton, 2009; Grayson \& Martinec, 2004; Peterson, 2005) rather than "fake" or "manufactured" (Askin \& Mol, 2018; Peterson, 1997). Artifacts are not inherently authentic. Rather, people attribute authenticity to them (Askin \& Mol, 2018). 
Irreplaceable artifacts are particularly important for the maintenance of institutions related to heritage. Heritage institutions refer to sets of institutionalized ideas, practices and artifacts that govern which elements from the past are being brought into the present to sustain contemporary collective identities, shared values, and social structures. Heritage institutions create meaning by bridging time as Smith explains in a reflection on her empirical work: “Heritage wasn't only about the past - though it was that too - it also wasn't just about material things - though it was that as well - heritage was a process of engagement, an act of communication and an act of making meaning in and for the present." (2006, p .1). Heritage institutions evoke the past not only discursively, but also through irreplaceable artifacts.

Irreplaceable artifacts face the challenges of material decay and loss of functionality. Whereas a little patina adds value to an irreplaceable artifact, showing that it has been used and connecting the artifact to the past, its decay or loss of functionality diminishes its ability to bring the past into the present. The latter situation prompts the question of whether to forgo its contemporary use or to adapt the irreplaceable artifact. The former option favors a gradual erosion of the heritage institution that it sustains. In contrast, the latter choice proactively favors the link between the past and the present, which helps maintain the institution that relies on the irreplaceable artifact. In this case, a key challenge consists in adapting the irreplaceable artifact without sacrificing its authenticity in the process. The practices involved in this process can be described as authentication.

Authentication refers to a thoroughly relational process through which artifacts come to be established as authentic (Askin \& Mol, 2018). Authentication is essentially "the process by which authenticity is socially produced and ascribed" (ibid, p. 164). This process, which occurs during social interaction, engages a variety of actors in the co-construction of authenticity (Askin \& Mol, 2018; Lehman, O’Connor, Kovács \& Newman, in press). Authentication may take place when an artifact's authenticity is established for the first time, such as when a newly 
discovered painting is certified as being the original work of a famous artist. In a religious context, authentication can also take the form of consecration, that is, a set of practices that establish an artifact as sacred (Jones \& Massa, 2013). Authentication is also in play when an irreplaceable artifact, previously established as authentic, undergoes repair or adaptation to maintain its contemporary functionality. In this process, the artifact risks losing its perceived authenticity, which calls for renewed authentication to establish its continued status as an irreplaceable artifact. To exemplify, an old church that is converted into a tourist office requires renewed authentication to maintain its affiliation with the institutions of religion or architectural heritage, without which it no longer sustains any of these institutions. We focus in this paper on the renewal of authentication in the context of modifying irreplaceable artifacts. To illuminate how authentication unfolds in this context, we ask the following research question: how do actors preserve the authenticity of irreplaceable artifacts that are essential for institutional maintenance?

Our empirical study examines the institutional maintenance of architectural heritage, which relies for its maintenance on irreplaceable artifacts known as "listed buildings." Listed buildings are protected because they represent artistic styles or historical periods that are deemed to have symbolic and/or artistic value for the nation state (Council of Europe, 1985). More specifically, we analyze the authentication of six listed buildings that were subjected to contemporary adjustments (Rouillard, 2006), aimed at their renovation or extension. All were at high risk of losing either their functionality or their authenticity in the process but maintained both and thus consolidated their inclusion on the national inventory of listed buildings. To make our findings robust across national contexts, we selected cases from both Denmark and France, which have similar practices in place to protect listed buildings and thereby maintain the institution of architectural heritage (Jokilehto, 1986). 
We identified three distinct forms of authentication that imbue irreplaceable artifacts with their potency for institutional maintenance, which we labelled as material consolidation, crafts mobilization and character enhancement. Although one form of authentication predominated in each case, we suggest that these three forms may be used in combination with one another to engage and satisfy different participants in the authentication process. These findings contribute to the literature on institutional maintenance with insight into how actors establish material artifacts as authentic through relational processes that draw selectively on material features, verbal discourse and practices. Collectively, they offer a novel, complementary role for material artifacts in institutional maintenance, extending previous work that has begun to unpack how material artifacts interact with verbal discourse and practices during institutional maintenance work (e.g., Jones \& Massa, 2013; Lanzara \& Patriotta, 2007; Patriotta et al., 2011).

\section{ARTIFACTS IN INSTITUTIONAL MAINTENANCE WORK}

Institutional maintenance work refers to the proactive engagement of actors in the continuous existence of established institutions (Lawrence \& Suddaby, 2006). Such work is particularly visible in the context of a pending threat of deinstitutionalization (Barin Cruz, Aguilar Delgado, Leca \& Gond, 2016; Blanc \& Huault, 2014) and under conditions of institutional complexity (Smets \& Jarzabkowski, 2013). Neglect can also make institutions subject to gradual erosion (Dacin et al., 2010; Lawrence et al., 2013; Zucker, 1988). We have limited insights into the gradual erosion of institutions (Barin Cruz et al., 2016; Lawrence, Leca \& Suddaby, 2009; Lok \& De Rond, 2013), and the collective 'silent' work of maintenance in which actors engage to prevent it (Micelotta \& Washington, 2013, p. 1139).

Institutional maintenance work draws on verbal discourse (Bitektine \& Haack, 2015; Patriotta, et al., 2011), practices (Dacin et al., 2010; Sillince \& Barker, 2012), and material 
artifacts (Boxenbaum, Huault \& Leca, 2016; Jones et al., 2013; Pinch, 2008; Rao, Monin \& Durand, 2005). Although verbal discourse is deemed essential for institutional maintenance (Currie, Lockett, Finn, Martin \& Waring, 2013; Raviola \& Norbäck, 2013), scholars advocate for empirical studies to deemphasize verbal discourse (Bitektine \& Haack, 2015; Patriotta et al., 2011) in favor of a greater focus on practices (Dacin et al., 2010; Sillince \& Barker, 2012) and material artifacts (Boxenbaum et al., 2016; Jones et al., 2013). Scholars argue, for instance, that "an emphasis on ideas as primarily linguistic has led institutional scholars to overemphasize the cognitive (Lawrence \& Suddaby, 2006) and neglect the material aspects of institutions" (Jones \& Massa, 2013, p. 1102).

Recent work on institutional maintenance gives increased voice to materiality. Institutionalists recognize that "material artifacts ... are important 'tools' for the institutional work of actors" (Greenwood, Oliver, Lawrence \& Meyer, 2017, p. 15; Dover \& Lawrence, 2010; Leca \& Naccache, 2006), perhaps even essential for institutional maintenance (Monteiro \& Nicolini, 2014). According to recent empirical studies, material artifacts are instrumental for the reproduction of institutionalized practices (Zilber, 2011), the legitimation of meaning structures (Lanzara \& Patriotta, 2007), and the reinforcement of patterns of social relations (Jones \& Massa, 2013). For instance, "buildings embody the cultural meanings, material and technological practices, and identities of their time and place ... They affect social life in profound ways and can be a means to reinforce ... the institutional order" (Jones \& Massa, 2013, p. 1129). Artifacts also help institutionalized ideas diffuse widely (Czarniawska \& Sevón, 1996; Rafaeli \& Vilnai-Yavetz, 2004), persist over time (Jones et al., 2013) and adapt themselves to different contexts (Czarniawska \& Joerges, 1996; Lawrence et al., 2013; Suárez \& Bromley, 2016). Despite this growing attention to material artifacts, institutional maintenance work constitutes an area with significant promise for further theoretical 
development (Greenwood et al., 2017), notably in terms of how artifacts interact with discourse and practices to maintain institutions.

\section{Interactions Between Artifacts and Discourse During Institutional Work}

Prior literature has begun to unpack how artifacts and verbal discourse interact during institutional work. One strand of this literature elaborates on the encoding of ideas into material artifacts, whose somewhat fixed and durable nature enables "institutions to cohere and endure over time" (Jones \& Massa, 2013, p. 1127). Essentially, Jones and Massa (2013) construe artifacts as stabilizing repositories for ideational features of institutions and propose that artifacts play a defensive role by supporting and anchoring the discursive features of institutional work. Accordingly, they call for institutionalists "to attend more seriously to the institutional work accomplished through buildings and by buildings" (ibid, p. 1129). Presenting a related argument about the role of materiality in institutional maintenance work, Lanzara and Patriotta (2007) suggest a recursive relationship between materiality and discourse. They draw on insights from actor-network theory to conceptualize artifacts as reinforcing, sometimes even reifying, established practices and ideational features of institutions. In this conception, artifacts stabilize and anchor ideas that may otherwise be ephemeral, sometimes preventing institutions from adapting to environmental changes.

A second strand of literature construes artifacts as "tests" of competing ideas. Building on Boltanski and Thévenot (2006 [1991]), Patriotta et al. (2011) interpret artifacts as objects that are mobilized in "tests of worth" to substantiate and negotiate competing ideational claims for legitimacy. Artifacts, they argue, offer significant interpretive flexibility in as much as "words and objects acquire different meanings depending on the context in which they are deployed" (ibid, p. 1831). Since the meaning of artifacts is malleable, actors engage in social interaction to negotiate the ability of an artifact to support an ideational element that is 
expressed through verbal discourse. Artifacts help actors arbitrate between competing ideas by determining their respective pragmatic legitimacy (Suchman, 1995).

Both streams of work give primacy to verbal discourse and cast artifacts in a supportive role of either transmitting or assessing verbal discourse. However, none of them addresses the particular properties of an artifact that makes it more or less suitable - and effective - for institutional maintenance. Notably, prior work does not distinguish between replaceable and irreplaceable artifacts. Yet, this distinction is crucially important for the maintenance of some institutions. For instance, the replacement of an original piece of artwork cannot be replaced by a reproduction without gradually eroding the institution of art museums. This is so because "even the most perfect reproduction of a work of art is lacking in one element: its presence in time and space, its unique existence at the place where it happens to be" (Benjamin, 1968 [1935], p. 214, cited in Askin \& Mol, 2018, p. 162). This uniqueness imbues irreplaceable artifacts with a high capacity for institutional maintenance. Uniqueness as a key property of irreplaceable artifacts has been broadly conceptualized under the terminology of authenticity.

\section{The Authenticity of Artifacts as Institutionally Shaped}

As previously mentioned, the authenticity of an artifact refers to the widespread perception that it is genuine, original, or true (Carroll, 2015; Carroll \& Wheaton, 2009; Grayson \& Martinec, 2004; Peterson, 2005). Previous literature has established that different forms of authenticity exist (Carroll, 2015; Carroll \& Wheaton, 2009; Lehman et al., in press) and articulated some institutional underpinnings of authenticity (Askin \& Mol, 2018). Importantly, authenticity is also a relational construct in the sense that "authenticity is a claim that is made by or for someone, thing, or performance and either accepted or rejected by relevant others" (Peterson, 2005, p. 1086). In practice, it is often, but not always, an object of social interaction in which producers and audiences (e.g., users and consumers) collectively establish an artifact 
as being authentic, thereby authenticating it (Askin \& Mol, 2018; Lehman et al., in press). Testifying to the relational constitution of authenticity, Carroll and Swaminathan (2000) show that experts found major brewers to make excellent "microbrew", yet consumers considered their brew to be inauthentic on the grounds that they were mass producers, that is, they did not have the craft-based identity of micro-brewers. In another study, Hahn and Zuckerman (2014) show that audiences tend to suspect high-status actors of being inauthentic and hence regard their cultural products as lacking in authenticity. In such situations, intermediaries may be brought in to help audiences engage in authentication. Glynn and Lounsbury (2005) show in a study of the Atlanta Symphony Orchestra that professional critics actively guided targeted audiences in their interpretations of cultural products to obtain their endorsement of producers' authenticity claims. Essentially professional critics helped consumers connect the artifact to broader institutional meaning systems that enabled them to construe the artifact as authentic (ibid).

Although processes of authentication are thoroughly relational, institutions shape the social interactions that produce authentication. Institutions condition authenticity by shaping which markers are deemed legitimate indicators of authenticity (Askin and Mol, 2018). One marker of authenticity is history: an artifact may be regarded as authentic because it has been associated historically with significant people, events or places, such as having belonged to a famous person (Carroll \& Wheaton, 2009; Dutton, 2003). Such associations may come to reflect shared understandings about the artifact's origins or past symbolic significance even if these associations were produced post hoc, that is, much later than the artifact (Askin \& Mol, 2018, p. 164). For instance, Hatch and Schultz (2017) show how Carlsberg symbolically reinterpreted a historical inscription of "Semper Ardens" on a stone entrance at corporate headquarters to claim authenticity for a new beer product, the Semper Ardens beer. The historical inscription existed prior to, and entirely independently from, the product that it later 
imbued with authenticity. Historical artifacts may also be adapted materially to enhance their perceived authenticity. For instance, the backsides of buildings are sometimes created artificially for guides to be able to tell compelling stories about social life behind the scenes, which appeal to tourists in pursuit of authentic experiences (MacCannell, 1973). Even if materially adapted for story-telling purposes, historical artifacts operate as institutionalized markers of authenticity.

Another marker of authenticity is category fit: artifacts can gain authenticity from fitting appropriately into an institutionalized category (Carroll, 2015; Carroll \& Wheaton, 2009; Lehman et al., in press). Peterson $(1997 ; 2005)$ shows, for instance, that producers of country music successfully established, in interaction with audiences, that their music was authentic on the grounds that it reproduced features of exemplar country music by Hank Williams. Category fit pertains not only to products but also to social identities. For instance, professional skills and experience are used as markers of authenticity when actors use appropriate techniques and ingredients to produce artifacts and to showcase them as authentic (Carroll, 2015; Carroll \& Wheaton, 2009). For instance, microbrewers used their social identities as traditional craft-like producers to establish, in interaction with U.S. consumers, that their beer products were more authentic than mass-produced beer (Carroll \& Swaminathan, 2000). Similarly, when Hank Williams famously claimed that "you have to plow a lot of ground and look at the backside of a mule for a lot of years to sing a country song” (Peterson 1997, p. 217), he also drew on social identity categories as a marker of authenticity.

There is also a temporal dimension to the institutional underpinnings of authentication. Institutionalized markers of authenticity evolve over time, re-shaping how actors interpret artifacts and attribute authenticity to them as they engage in social interaction (Carroll \& Wheaton, 2009; Glynn \& Lounsbury, 2005). To illustrate this temporal dimension, Peterson (2005) shows that authenticity became increasingly attributed to original artifacts, and less so 
to their modernized form, when industrialization made it possible to (re)produce any object through mass production technology. A more recent example is the evolving conceptualization of buildings and cities from static structures to living organisms (Pendlebury, Short \& While, 2009). This development affects importantly how actors negotiate the authenticity of buildings and cities during their social interactions (see also Colombero, 2015 for an elaboration of how disparate groups of actors negotiate the authenticity of buildings with one another).

Whereas previous literature establishes that authentication has institutional underpinnings in the form of evolving markers of authenticity, we know little about how authentication impacts on institutional maintenance. To shed light on this topic, we conducted an empirical study of how actors authenticate irreplaceable artifacts as a part of their institutional maintenance work.

\section{METHODOLOGY}

\section{Case Selection}

To make our findings theoretically robust (Yin, 2013), we selected cases from two countries - Denmark and France. This choice prevented our findings from being tied to a specific national context in as much as institutional practices related to architectural heritage are quite similar in the two countries (Jokilehto, 1986), reflecting the principles outlined in the Convention for the Protection of the Architectural Heritage of Europe (Council of Europe, 1985). This convention requires member states to keep a national inventory of architectural heritage, commonly referred to as "listed buildings". The Danish inventory of architectural heritage currently lists 9.000 buildings (in 3.600 building complexes) and the French equivalent 43.000 buildings. The Cultural Protection Office (CPO), located within the Ministry of Culture in each country, manages the inventory of listed buildings and issues permits for contemporary 
adjustments to the listed buildings. Their work is governed by the Danish Act on Listed Buildings and Preservation of Buildings and Urban Environments (2011), respectively the French Historical Monuments Law (1913) within the Heritage Code (2014).

We selected six listed buildings for in-depth analysis, three in each country. We chose listed buildings that were undergoing (or had recently undergone) contemporary adjustments involving new materials and where the actors involved actively sought to maintain the building on the national inventory of architectural heritage and to keep the function that the listed building had at the time of its inclusion on the national inventory of architectural heritage. As such, we excluded cases of adaptive reuse (see Brand, 1995), such as the conversion of a church into a café. We also excluded listed buildings that were difficult to access, such as buildings belonging to the Danish Royal Family. In addition to these basic criteria, our case selection relied on extreme cases of authentication, i.e., cases that involved very significant modifications or that carried particularly high significance in the country. Using these criteria, we selected two listed buildings that were deemed to be very significant expressions of architectural heritage: the Danish Nyboder and the French Pantheon. Two other cases involved contemporary adjustments that implied significant amounts of new materials: the Danish Sølvgade Skole and the French École des Mines de Paris. The last two cases involved dramatic transformations of the original building: the Danish Munkegård Skole and the French Molitor swimming pool. All six cases are briefly summarized in Table I and depicted in Figure 1.

INSERT TABLE I AND FIGURE 1 ABOUT HERE

\section{Data Sources and Data Collection}


Following a constructivist approach (Justesen \& Mik-Meyer, 2012), we gained familiarity with the institution of architectural heritage through historical accounts (e.g., Sire, 2005; Jokilehto, 1986), guidelines on the restoration or renovation of listed buildings (e.g., Rouillard, 2006; Viollet-le-Duc, 1863), and general information on architecture (e.g., Pérouse de Montclos, 1972). We also read the relevant international charters and conventions produced by the Council of Europe $(1954 ; 1969 ; 1975 ; 1985 ; 2005)$, UNESCO (1972; 1977 and subsequent operational guidelines), ICOMOS (1994; 2003; 2008; 2014a; 2014b) and professional associations (ICCROM, 1931; 1964; 2008). At the national level, we consulted contemporary regulatory texts, such as the Danish Building Regulation (BR-10) and the French Heritage Code to become familiar with national practices related to architectural heritage. This archival material helped us draw the contours of the institution of architectural heritage and its evolution over time. It also sharpened our data collection and analysis, enabling triangulation with interview data (Miles \& Huberman, 1994).

Our primary data collection from the six cases includes interviews with key actors involved in contemporary adjustments to one or more of the listed buildings that we had selected for in-depth analysis. Interviews remain the most useful method for interpretive inquiry (Denzin \& Lincoln, 2000), allowing researchers to view the focal phenomenon from the perspectives of actors (Eisenhardt \& Graebner, 2007). We used semi-structured interviews in order to stimulate interviewees' thoughts about the selected themes. We asked informants about the criteria and ambitions that guide contemporary adjustments, the ambitions for the contemporary adjustments, and their interpretations of the listed building's defining characteristics. In total, we conducted 24 interviews with key actors involved in contemporary adjustments to listed buildings (see Table II for details). These interviews, which constitute our primary data source, lasted about 75 minutes each and were conducted at the actor's workplace or directly at the building site. They were all recorded and transcribed manually. 


\section{INSERT TABLE II ABOUT HERE}

We collected additional data on the six cases from archival material and observations. The archival material consists of calls for bids and corresponding proposals for contemporary adjustments to the selected listed buildings. We gained access to this material through interviewees in the majority of cases. We also collected descriptions of the listed building and architects' drawings when they were available and not confidential. In addition, we engaged in nine episodes of non-participant observations where we observed decision-making processes related to upcoming or on-going contemporary adjustments. Our aim was to observe the actors in their natural settings (Gold, 1969), gather informal and tacit knowledge (Polanyi, 1966), and identify taken-for-granted assumptions and rules of organizational members (Charmaz \& Olesen, 1997). We wrote 39 pages of observational notes, which were later transformed into descriptive, analytic and reflexive notes (Eriksson \& Kovalainen, 2008). Given that our interpretations constituted our actual study tools (Esterberg, 2002), we contacted two architects who were not informants for the study to engage in respondent validation (Kvale, 1996). Their feedback on our emergent analysis helped us refine our understanding of how architects and other specialists proceed to make contemporary adjustments to listed buildings without jeopardizing these buildings' inclusion on the national registry of architectural heritage.

\section{Data Analysis}

Our data analysis aimed at identifying how architects and other specialists engaged in contemporary adjustments sought to maintain the historical and artistic qualities that confer authenticity upon a listed building. We conceptualize these efforts as an act of authentication 
T0656

(Askin \& Mol, 2018) that qualifies as institutional maintenance work when the actors actively engage in maintaining the institution of architectural heritage.

With inspiration from the qualitative coding techniques of Corley and Gioia (2004) and Gioia, Corley and Hamilton (2013), we first engaged in open coding of our interview data, generating first-order codes that reflected the actions and intentions of informants. Examples include: "keeping intact both internal and external structures", "adding new building elements that resemble original ones" and "highlighting symbolic relations between building and national history". Our second order codes emerged dynamically through axial coding, i.e., cycles of data collection and data analysis in which we looked for similarities and differences across our six cases to strengthen the conceptual coherence of our analysis (Strauss, 1987). Table III provides examples of our second order codes.

\section{INSERT TABLE III ABOUT HERE}

In labelling our second order codes, we iterated between our first order codes and the theoretical concept of authenticity (see Figure 2). This process resulted in three aggregated dimensions that represent different forms of authentication that actors draw upon to socially construct the authenticity of a listed building undergoing contemporary adjustments.

\section{INSERT FIGURE 2 ABOUT HERE}

In this last analytical step, theoretical coding, we first identified Material Consolidation - i.e., maintaining original materials of a listed building or using its material surroundings - as a traditional form of institutional maintenance work, one that reflects highly institutionalized practices relating to architectural heritage. We classified Crafts Mobilization - i.e., using 
traditional forms of craftsmanship to confer authenticity upon new materials - as an intermediate and somewhat flexible form of institutional maintenance work, one that reflects practices that have been endorsed in international conventions for more than fifty years. The last form of authentication, Character Enhancement - i.e., emphasizing immaterial dimensions of authenticity to confer authenticity upon a listed building that has undergone significant material alteration - appears to be a more controversial and highly elastic form of institutional maintenance in that it draws rather freely on a listed building's symbolic significance and the contemporary context to establish its authenticity. This latter form of authentication, which is only partially institutionalized in relation to architectural heritage, enables gradual institutional change.

\section{FINDINGS}

Authentication is, as previously mentioned, a thoroughly relational process that takes shape during social interactions, which are themselves shaped by evolving institutionalized markers of authenticity. The first part of our findings describes the latter, whereas the second part addresses the three forms of authentication that emerged from social interactions among multiple actor groups involved in making modifications to the six irreplaceable artifacts that we studied. Actor groups include professionals who propose and carry out modifications, actors who finance this work, state representatives who validate it - often dedicated architects from Cultural Protection Offices (CPO) - as well as owners and users with stakes in an architectural heritage building. Although they occupy different roles and exert differential influence on decisions, they all participated in the relational processes that resulted in the renewed authentication of these irreplaceable artifacts following significant modifications to ensure their continued functionality in contemporary society.

\section{Evolving Definitions of Authenticity in Architectural Heritage}


Institutional markers of authenticity manifest in international charters and conventions pertaining to architectural heritage. The first international document to mention authenticity in relation to architectural heritage is the Venice Charter (ICCROM, 1964), which emphasized a collective moral duty to protect our common cultural heritage by preserving the authenticity of buildings. Authenticity was not defined in the Venice Charter but appeared more than a decade later in UNESCO's (1977) Operational Guidelines for the Implementation of the World

\section{Heritage:}

"The property should meet the test of authenticity in design, materials, workmanship and setting; authenticity does not limit considerations to original form and structure but includes all subsequent modifications and additions over the course of time, which in themselves possess artistic or historical values." (art. 9, p. 3, original emphasis).

Notable in this definition is the emphasis on design, material, workmanship and setting, which are all material features. This focus shaped early institutionalized understanding of how authenticity applies to architectural heritage.

This initial definition of authenticity broadened over time to also include immaterial features. The Nara Document on Authenticity (ICOMOS, 1994) extended the scope of authenticity significantly beyond material expressions to also include intangible forms:

"Depending on the nature of the cultural heritage, its cultural context, and its evolution through time, authenticity judgements may be linked to the worth of a great variety of sources of information. Aspects of the sources may include form and design, materials and substance, use and function, traditions and techniques, location and setting, and spirit and feeling, and other internal and external factors. The use of these sources permits elaboration of the specific artistic, historic, social, and scientific dimensions of the cultural heritage being examined.” (art. 13). 
The novel elements in this definition are the use and function of listed buildings, as well as their spirit and feeling. In fact, use and function were mentioned in the Venice Charter (1964, art. 5), albeit not in relation to authenticity. In contrast, the inclusion of spirit and feeling extended beyond previous understandings of what authenticity means in relation to architectural heritage. Although these immaterial features generated controversy among architects and other relevant actors (van Balen, 2008), they were nevertheless included in subsequent charters and conventions, notably the Faro Convention (Council of Europe, 2005) and The Quebec Declaration of Spirit of Place (ICOMOS, 2008). Only few European countries, however, have signed the Faro Convention; neither Denmark nor France have done so, the latter for reasons of legal conflict (see http://questions.assemblee-nationale.fr/q14/14-77255QE.htm).

The immaterial markers of authenticity are often expressed as "spirit of place" or "genius loci". Taking inspiration from classical Roman religion and 18th century landscape architecture, Norberg-Schulz (1980) proposed that places have a "spirit" which cannot be described by ordinary analytical techniques. He mobilized the ancient notion of genius loci, which originally referred to the protective spirit of a place, to characterize the spirit that manifests in the physical features of a place and in the interpretations of the human experiences that have unfolded in that place through time (Rifaioglu \& Sahin Güçan, 2008, p. 1). NorbergSchulz proposed that genius loci can reside in 1) the topography of the earth's surface, 2) the cosmological light conditions and the sky as natural conditions, 3) buildings, and 4) symbolic and existential meanings in the cultural landscape.

Another, related expression of the immaterial features of authenticity is spirit of place. According to The Quebec Declaration of Spirit of Place (ICOMOS, 2008):

"Spirit of place is made up of tangible (sites, buildings, landscapes, routes, objects) as well as intangible elements (memories, narratives, written documents, festivals, 
commemorations, rituals, traditional knowledge, values, textures, colors, odors, etc.), which all significantly contribute to making place and to giving it spirit" (art. 1).

Not only does this document widens the scope of authenticity significantly, but it also emphasizes the dynamic, pluralistic, and socially constructed character of authenticity:

"Since the spirit of place is a continuously reconstructed process, which responds to the needs for change and continuity of communities, we uphold that it can vary in time and from one culture to another according to their practices of memory, and that a place can have several spirits and be shared by different groups." (ibid, art. 3).

This fluid conceptualization of authenticity encourages more negotiation among multiple actor groups than did previous definitions.

The most recent definition of authenticity ties the construct even tighter to perceptions of collective cultural identity. In the document Nara +20 , authenticity is defined as:

"A culturally contingent quality associated with a heritage place, practice, or object that conveys cultural value; is recognized as a meaningful expression of an evolving cultural tradition; and/or evokes among individuals the social and emotional resonance of group identity." (ICOMOS, 2014b).

This definition emphasizes immaterial features of authenticity, notably shared values and social identities, which reinforce the relationally constituted nature of authenticity. Although this understanding of authenticity does not inform national policies and laws for architectural heritage in Denmark and France, the architects in our study nevertheless included immaterial dimensions of authenticity in their justifications of contemporary adjustments to listed buildings. They did so in all three forms of authentication but all the more so in the form we refer to as Character Enhancement. 


\section{Three Forms of Authentication of Listed Buildings}

We identified three different forms of authentication that architects and other actors used to protect the authenticity of a listed building while introducing new materials into it. The three forms, Material Consolidation, Crafts Mobilization, and Character Enhancement, are all used to carry out contemporary adjustments to listed buildings that aim at maintaining the institution of architectural heritage. They are not simply different forms of authentication; they represent increasing degrees of freedom in terms of encouraging the institution to evolve.

\section{Material Consolidation}

Architects and other actors used Material Consolidation to authenticate a listed building when they kept as many original building components as possible during contemporary adjustments to a listed building despite the introduction of new materials. Material Consolidation was also in play when actors replaced damaged building components with equivalent ones from the same historical period, such as mullioned windows, stucco ceilings, or high foot panels that were in common use at the time. In using Material Consolidation, actors attributed authenticity to the materials themselves, not to how they were produced (see Crafts Mobilization) or to their symbolic significance (see Character Enhancement).

This form of authentication was predominant in the case of Danish Sølvgade Skole and French École des Mines de Paris. Sølvgade Skole is a public primary school located in central Copenhagen. Introduced as the school that "never gives up" (Siemsen, 1997), it is the oldest public school in Denmark that is still currently functioning as a school, which motivated its inclusion on the national inventory of listed buildings. Contemporary adjustments to this listed building were carried out to accommodate an increase in city population. The city of Copenhagen "faced the issue of the increasing number of newcomers in the city, which forced it to invest in new schools twelve years ago ... Out of 100 newcomers per month, $10 \%$ are 
children" (Pr. of Education History 1). The school needed to expand in order to continue to operate as a public primary school, which prompted the Municipality of Copenhagen to ask an established architectural firm to conceive and build an extension to the original building.

The lead architect faced the challenge of making an extension that would qualify as authentic although it was made entirely of new materials. Taking inspiration from the architect of the original school building, P. C. H. Hagemann, the lead architect designed an extension "that speaks the language of children - colorful and musical - while at the same time ensuring that the building respects its historical surroundings" (Lead Architect 2). The extension did not physically resemble the original school building, but it drew authenticity from the original building by visually extending its base into the new one, using what the lead architect described as "little plays", that is, partial reproductions of material elements that appeared on the base of the original school building. The point was "not to copy or anything but to focus on the stories - we did not try to make the same material or the same rhythm but only to suggest a relationship between the buildings!" (ibid). For instance, the lead architect gave the extension an odd physical shape to insert some distance between "the old and the new buildings ... so just they [the two connected buildings] could kiss each other here" (ibid). She conceived the new building as separate from, yet relationally connected to, the original school building, drawing on material features of original school to confer authenticity upon the extension. She also connected the extension materially to the original school building "through window glasses where pupils can see the old building” (ibid).

The lead architect and her team also relied on material properties to connect the building extension to the neighborhood. They made use of pastel colors, which the lead architect described as a historical reflection of Copenhagen as a neo-classicist city. The unique color system that they developed resonated with specific colors in some of the adjacent buildings in the neighborhood. For instance, the extension's facade and roof mimic colors found on gables 
in the neighborhood. To consolidate this approach to authentication, the architecture team applied the same unique color scheme inside of the extension. For instance, they selected "furniture which respect the colors system so everything is coordinated and accepted!" The architects materially reproduced not only colors but also shapes to suggest a relationship between the new building and older buildings in the same neighborhood. In the words of the lead architect, "we needed to design a modern building but also wanted to pay respect to the shapes of the area, the morphology, and also the coloring. With tweezers, the small details of an acupuncturist, we [the architects] listened to the neighbors here." (ibid). The re-use of colors and shapes from buildings in the neighborhood drew authenticity from the environment into the new building. This approach reflects Material Consolidation as a mode of authentication, one that proved effective for a building extension made entirely of new materials.

Material Consolidation was also used in contemporary adjustments to École des Mines de Paris, a highly renowned engineering school in France, which has trained elite engineers since the early $19^{\text {th }}$ century. This listed building is located very close to the French Pantheon in the Latin quarters of Paris, at the borders of the Luxembourg Garden. The school underwent contemporary adjustments to ensure that it could maintain its function as a school of higher education, a function that dates back more than a hundred years, that is, prior to its inclusion on the national inventory of listed buildings. The contemporary adjustments did not pertain to student capacity but to the technological installations that appeared outdated for a school representing the state of the art in engineering.

The challenge for the architects consisted in updating the classrooms to contemporary technological standards without sacrificing the building's authenticity. As the CPO architect explained: "This building has been used as a school forever, so it is very important that it can function as a school. In that case, we might say 'ok we have to go and compromise," (CPO Architect 3). The main compromise consisted in introducing new modern materials into the 
listed building without undermining the building's original aesthetic features. One contemporary adjustments pertained to the Conrad Schlumberger's Lecture Hall, which is used for lectures and colloquia and which carries the name of a prestigious engineer. Schlumberger is acclaimed worldwide as one of the most well-known alumni and professors of École des Mines de Paris. He conducted experiments on electric prospecting in 1911 (Robin, 2003) directly under the lecture hall that now carries his name. Paradoxically, the Schlumberger's Lecture Hall is the most obsolete auditorium in the building from the perspective of contemporary educational standards. The contemporary adjustments aimed also to showcase the school's innovation profile. The architects proposed to install equipment that would make the lecture hall useful as a MOOC facility and increase audience comfort, in addition to communicating the privileged place that this school holds within French academia and placing it on the map since École des Mines de Paris "is a school no one knows where is" (Client 5). The CPO architect saw the contemporary adjustments to the Schlumberger Lecture Hall as " $a$ prestigious event. Nevertheless, it remains just a first step ... a signal to show that the school is experiencing renovation ... is waking up!” (CPO architect 4). Through Material Consolidation, the architects sought to 're-awaken' and showcase the school's identity as a highly innovative actor.

Another use of Material Consolidation consisted in a proposal to increase the vegetalization of the original, protected terrace of the building. Although the CPO prohibited material modification of the terrace, the client's architect proposed "to have some green on top of the building as genuine [coal] mines are generally below the ground" (Architect 2). This proposal drew on the traditional - authentic - identity of École des Mines de Paris as a mining school to authenticate the listed building while introducing new materials into it.

This section showed that Material Consolidation as a form of authentication mobilizes material components to establish a listed building's authenticity. The unique, original building 
components of a listed building, or of its surrounding built environment, convey authenticity in a materially verifiable, and hence relatively uncontestable, manner.

\section{Crafts Mobilization}

When using Crafts Mobilization, architects and other actors involved in contemporary adjustments called upon specialist craftsmen who mastered the techniques that were in use at the time of constructing the original building to produce replacement building parts (e.g., window frames, board panels, doors) that had been destroyed and that could no longer be purchased. Actors relied on this form of authentication when original building parts, deemed important for the building's overall authenticity, were damaged and when equivalent replacement parts were unavailable. Two of the cases that we studied used this form of authentication to reproduce building components that had decayed beyond repair: the French Pantheon and the Danish Nyboder.

The French Pantheon is located in what used to be the church of Sainte-Geneviève, the patron Saint of Paris. Louis XV took the initiative to build this monument, which JacquesGermain Soufflot initiated in 1764 and Jean-Baptiste Rondelet completed after the French Revolution in 1789. Quatremère de Quincy subsequently transformed it into a memorial (cenotaph) of France's Grands Hommes, i.e., individuals who have made a significant contribution to the national construction of France. In 1885, after Victor Hugo's death, the Pantheon became a secular memorial building. This heritage building was listed in 1920 (extended in 2008) as a tribute to the French Republic. According to the CPO architect in charge of contemporary adjustments to the building, "the Pantheon is really a listed building apart because it is the symbol of the [French] nation" (CPO Architect 2).

The Pantheon building suffers from some structural problems that require frequent intervention. Viollet-le-Duc, a leading French architect from the $19^{\text {th }}$ century, attributed these 
structural problems to "its exaggerated height" of 83 meters (Quinet, 1883, p. 87). Architects involved in contemporary adjustments to the Pantheon sought first and foremost to maintain the material shell of the building and to structurally reinforce the building. To do so, they needed to replace some visible stones in its material shell. Instead of finding similar, naturally occurring stone, the architects opted to replace decaying stone with a material that had similar features to the original stone and that was produced in a similar manner. The material that they chose for replacement required scientific approval by the French Laboratory for Research on Historical Monuments, which they obtained before replacing the original stones with the new material. This act is an instance of Crafts Mobilization because it is the similar production technique that confers authenticity upon the new material.

Such authentication was not required for damaged materials that were invisible. Architects involved in contemporary adjustments to the Pantheon also ought to structurally reinforce the building by introducing new materials into the invisible building structure. To preserve the building's authenticity, they hid new materials behind original, visible ones. For instance, they used a new technology, carbon fibers, to reinforce the overall structure of the building. As the lead architect of the contemporary adjustments argued, carbon fibers "were stronger, more resistant and generated fewer problems in being integrated with the lead layer [relative to iron, the original reinforcement technology]" (Lead Architect 4). This invisible replacement of a building component did not affect the building's apparent authenticity.

The Danish Nyboder is a building complex conceived by King Christian IV and built in inner Copenhagen in 1631. It takes the form of almost endless rows of identical yellow buildings, each equipped with many small housing units. Nyboder is regarded as the first community of apartment buildings in Denmark. It was, and still is, a housing estate dedicated to the personnel and students of the Royal Danish Army and their families. Nyboder is located close to Øresund, the strait between Denmark and Sweden, which at the time was an ideal 
strategic location for the King to quickly assemble his naval troops and lead them to the ships in case of an imminent enemy attack from the seaside. This building complex carries symbolic significance in Denmark. According to the main sponsor of contemporary adjustments to Nyboder: "every schoolchild knows Nyboder, even if you are from Western Jutland, you eventually go with your history teacher to Copenhagen to visit all the important places, and you would definitely pass by Nyboder!" (Patron 1).

Facing material decay, Nyboder underwent contemporary adjustments to maintain its original function as a housing unit for the army/navy. The architects involved sought to replace decayed materials and to modernize the buildings by adding modern sanitary installations. To keep the buildings' authenticity, they re-used and repaired as many original materials as possible. As one architect explained: "The idea is to make the building as attractive and as modern as possible without putting the historical values in jeopardy. That is actually the point of what we do" (Architect 1). Their primary focus was to maintain the buildings' original exterior shape. They argued that it would have been detrimental to "alter the very obvious rhythm of [the raw structure], as that is the physical aspect where the value is stored. For instance, you cannot close a window as it would interrupt this value. Same with the chimneys, one cannot remove [them], because it will also interrupt the rhythm." (Lead Architect 1). In contrast, the interior of the buildings was deemed more modifiable. The apartments required significant intervention to make them functional since water erosions had decayed some of the wooden building components. In some instances, the architects asked specialized craftsmen to reproduce wooden building components that had decayed, such as foot panels and door knobs that were no longer available on the market. The craftsmen used traditional craft methods to imbue these replacement objects with authenticity.

Importantly, the apartments also needed better ventilation and modern sanitation equipment, such as access to a private bathroom, to make them functional and appealing to 
contemporary residents in military training. The architects obtained permission from the CPO and other stakeholders to install "a new window in cast-iron [like the previous original one] that was made to resemble the old window. So basically, it looks like a roof window but it is not a roof window, it is a place where inhabitants can get rid of humidity and ventilate the apartment" (Architect 1). In building a new window by means of traditional production methods, the actors used Crafts Mobilization to confer authenticity upon new materials. In this case, the new materials did not replace original ones, but were added to the listed building.

While the new ventilation materials were approved, the modernized bathrooms posed challenges for authenticity. The representative of the Cultural Protection Office (CPO) was disappointed in the bathrooms, which were "maybe too luxurious because Nyboder's houses are very humble homes and [she] would like the bathrooms to be humbler. It is ok that there are bathrooms because that is a part of the way we live today, of course we need bathrooms; but [she] would have liked to have an interior that was humbler" (CPO Architect 1). In contrast to the new roof windows that were crafted with traditional production methods, the modern bathroom installations could not rely on Crafts Mobilization to imbue the new bathroom facilities with authenticity, given that these new installations did not exist at the time. Although the CPO eventually approved the modernized bathrooms, this contemporary ad did not quite meet the authenticity requirements, and hence detracted somewhat from the overall perceived authenticity of the listed building.

This section showed Crafts Mobilization as a form of authentication in which actors use traditional methods of craftsmen to produce replacement building components, using new materials. They derived authenticity from the methods of production rather than from the materials themselves. 


\section{Character Enhancement}

When using Character Enhancement, architects and other actors referred to a particular spirit, or genius loci, which characterizes the listed building in question (see the first section of findings for details) to authenticate a listed building. This form of authentication was used when new materials were introduced into a listed building without replacing original building components and without their being produced using traditional crafts. In other words, the newly added components had no tangible ties to either the building or its historical context. The ties to the past were purely symbolic and immaterial in nature.

This mode of authentication was used by architects and other actors during contemporary adjustments to the Danish Munkegård Skole and the French Molitor. Munkegård Skole is a public, primary school, located in Gentofte, an affluent neighborhood north of Copenhagen. Designed between 1954 and 1956 by the Danish architect Arne Jacobsen, Munkegård Skole is regarded as an exemplar of quality public constructions from the 1950s. Arne Jacobsen is considered the most highly reputed Modernist architect in Denmark. Contemporary adjustments to the school building were deemed necessary because of overcrowding. This listed building required not only renovation but also significant extension of capacity.

The architects and other actors engaged in contemporary adjustments to Munkegård Skole sought first and foremost to enlarge its capacity without compromising its status as a listed building. In year 2000, the municipality of Gentofte had asked the CPO to remove this school from the national inventory of listed buildings in order to facilitate the installation of new IT facilities, equipment to support project-based learning, and climate control in the classrooms (see Referat 19/11-2003). The CPO refused, prompting architects to find alternative solutions for how to keep this listed building functional as a public school. CPO architects did not want the building to turn into a museum, arguing that "for generations you will still be able 
to tell the story in apps, books or posters or something else, [but] at some point that legacy is forgotten, and then you only have the shell unless you can continue with the same functionality" (CPO Architect 1).

The subsequent initiative consisted in extending the capacity of the school to enable it to continue functioning as a primary school while remaining a listed building. The architects renovated the old classrooms and built an underground extension to extend capacity. In the process, they destroyed and reconstructed the original courtyards to provide a more coherent school structure and to find solutions to various issues relating to new school regulations. In the original building, rooms were expanded to twice the original size to accommodate the increasing number of pupils. According to stakeholders, "the only thing we were allowed to do [in the original school building] was the creation of sliding doors. But we had to use the same material as the other doors in the existing school building [...] but it would have been visible, which we found problematic in terms of authenticity” (Lead Architect 3). Since the original school building was protected, the architects proposed an underground extension to expand capacity.

A core challenge consisted in imbuing the brand-new underground extension with authenticity. For this purpose, the architects applied a motif from Arne Jacobsen wallpaper on bathroom doors in the underground extension. As one actor astutely remarked: "this motif was not even present inside the original school" (Client 3). Both the client and the CPO nevertheless accepted this solution as authenticity-enhancing. The Munkegård architect was also satisfied with the results, remarking that "the new part is so well integrated in the old building that I hope it will be seen as a whole, as a new Munkegård Skole” (Lead Architect 3). In using this wallpaper motif to confer authenticity on the new underground extension, the architects drew on the character of Arne Jacobsen. They employed the form of authentication that we call 
Character Enhancement in as much as the motif had no material connection to the original building.

Character Enhancement was also used extensively as a form of authentication in the contemporary adjustments made to the French Molitor swimming pool. Located in the chic west side of Paris, Molitor was built in 1929 in Art-Deco style. It became an iconic Parisian swimming pool and meeting place, not least after the outfit known as a 'bikini' was introduced there for the first time in history, shortly after WWII (Roubaudi \& Jorion, 2014). The Molitor spurred the imagination of many artists. For instance, the name of the main character in the Life of $\mathrm{Pi}$ is a diminutive of Piscine Molitor (Martel, 2001). In 1989, Molitor was closed down and turned into a famous venue for underground street-art. It became a listed building in 1990, notable for its aesthetics features in Art-Deco style. In 2008, a complete refurbishment of Molitor was initiated to "allow the true rebirth of the building" (Client 6) by restoring it to its original function as a swimming pool, keeping intact the layout of the two pools. The complete refurbishment meant that the client "entirely destroyed the old building and rebuilt it" (Lead Architect 5), a process that required significant authentication. Drawing on immaterial features of authenticity, the client proposed to construe authenticity as a construct-in-the-making, not as an indicator of the building's historical origins:

"I am honored to have shaped a new authenticity for Molitor! Not me personally because I was not alone of course, but we did give it a new authenticity! Nobody comes for the original mosaic [...] or because it is a listed building; come on ... no one cares! So let us take a deep breath. When one enters the lobby, one will look at works of art, just as the people who worshipped Molitor liked it because it was a crazy place, because every time they visited, there were new artworks by new artists, etc. That is what people remembered about Molitor and what they hope to recapture" (Client 6). 
In entirely overhauling the interior of Molitor, the architects nevertheless restored some of the original aesthetics. They emphasized the original colors and replaced the original mosaics after studying them meticulously: "We made a materials library and when the elements were rebuilt, we compared the new against the old to verify that they were consistent with one another, except that the new materials had completely different technical features!" (Lead Architect 5). The new technical features of the replacement components met new regulations for sanitization.

Although the architects used material features selectively to authenticate the overhauled listed building, their main approach was that of Character Enhancement. The client sought, first and foremost, to restore the unique spirit of the Molitor, which is expressed vividly in an annotated photography book about the re-making of the Molitor (Roubaudi \& Jorion, 2014). In this book, the client characterizes the 'spirit of place' (see the first section of the findings) in the following words (ibid, 2014, p. 8):

"The pools were empty but had been lived in by artists who had all left traces of their work. The walls had lost their rendering, but everywhere there were poetic remains of a golden age. The colours had faded, but in the light filtering through the glass ceiling, the famous "Molitor yellow" was still vibrant on the sides on the changing cubicles. We almost thought we could hear kids laughing, and see outlined against the light, Johnny Weissmuller who was a swimming instructor at Molitor. After the few visits, we began to see the soul of the place, what made it unique: the two pools of course, the incredible volumes, the powerful style, but above all the generations that had gone there throughout Molitor's different lives. The walls had retained all this."

This emphasis on Character Enhancement as a mode of authentication expressed itself in the architects' decision to create a walkway around the main pool, which was surrounded closely 
by changing rooms. They kept the original doors of the changing rooms but reduced the space inside of them so much that they could no longer be used as changing rooms. This intervention met the CPO's requirements for authenticity, but carried little significance for the client, who remarked that "they [the doors] were just decorative ... the aim was just to satisfy the CPO architects, even though they agree that their approach to the protection of patrimony is excessively narrow” (Client 6). Emphasizing the Molitor's spirit of place over the re-use of its original material components, the client engaged the architects responsible for carrying out contemporary adjustments in using Character Enhancement to authenticate this listed building. These actors also conformed minimally with CPO requirements for the (re-)use of original materials to collectively establish the Molitor as authentic despite a complete overhaul of the original material building.

This section showed Character Enhancement as a form of authentication that relies on immaterial forms of authenticity, such as spirit and feelings, to confer authenticity upon new materials that are being introduced into a listed building during contemporary adjustments.

\section{DISCUSSION}

Our empirical study illuminated two key elements of authentication. The first one pertains to how institutionalized understandings of authenticity have evolved in the context of architectural heritage. Our study showed how such understandings have matured over the past five decades, and also expanded from an emphasis on material features of authenticity to an increasing focus on immaterial dimensions, such as spirit and collective identity. This evolution has made the concept of authenticity more fluid and subject to ongoing negotiations among different actor groups during social interaction. The second element of authentication relates to how actors, influenced by these evolving institutionalized understandings of authenticity, proceeded during social interaction to establish listed buildings as authentic while carrying out 
contemporary adjustments to ensure their continued functionality in contemporary society. Ultimately authentication confirmed the listed buildings' status as irreplaceable artifacts, continuously able to draw the past into the present and thereby contributing to maintaining the institution of architectural heritage.

We identified three forms of authentication used in institutional maintenance work: Material Consolidation, Crafts Mobilization and Character Enhancement. Material Consolidation relies on original, tangible objects to authenticate artifacts. Such objects were integral components of the irreplaceable artifact itself or belonged to its physical surroundings. Crafts Mobilization draws on traditional practices for authentication, that is, professional practices that were in use at the time of making the original artifact. By using traditional practices to produce new building components, actors authenticated repairs or adaptations to the irreplaceable artifact, even when these components were made entirely of novel materials. Character Enhancement uses symbolic features to authenticate an artifact. Symbolic features represented in our study a person or a local community that was tightly associated with the irreplaceable artifact. Actors used Character Enhancement to establish a listed building as representative of a symbol and made adaptations to this irreplaceable artifact in congruence with this symbol. In our empirical study, actors tended to emphasize one form of authentication over the others although all six cases used more than one form of authentication to justify contemporary adjustments to a listed building. Since the three forms of authentication were used in combination with one another, they appear to not be mutually exclusive.

Our findings have implications for the literature on the role of artifacts in institutional maintenance work. In contributing to this literature, our findings also connect institutional maintenance work to authentication in another way than through identification (see Creed, 
DeJordy \& Lok, 2010; Nilsson, 2015), namely through other artifacts, past practices and highly symbolic discourse.

\section{Roles of Artifacts in Institutional Maintenance Work}

Institutional scholars have recently underlined that institutional maintenance work constitutes an area with significant promise for further theoretical development (Greenwood et al., 2017). In this study we pursued one fruitful area of development, namely a better articulation of the role of artifacts in institutional maintenance. Previous literature has begun to unpack how artifacts, in combination with verbal discourse and practices, contribute to institutional maintenance (Jones \& Massa, 2013; Lanzara \& Patriotta, 2007; Patriotta et al., 2011). Essentially, previous works suggest two different ways in which artifacts interact with discourse in institutional maintenance. In one account, artifacts are construed as ideational repositories. Jones and Massa (2013) and Lanzara and Patriotta (2007) both construe artifacts as stabilizing forces that help ideas, which have been encoded into them, endure over time. In another account, artifacts are construed as a testing apparatus for ideas. Patriotta et al. (2011), propose that the meaning of artifacts is sufficiently malleable for them to be mobilized for testing the validity of discursive claims in specific contexts.

These previous studies focus on how actors produce or use artifacts, but they largely remain silent on the suitability of these artifacts for use in institutional maintenance. The question of which qualities of an artifact make it effective for institutional maintenance, however, is crucial to institutions that rely on what we refer to as irreplaceable artifacts.

Artifacts are deemed irreplaceable when they are construed as authentic, i.e., as unique, genuine or "true to" something in contrast to being "fake" or "manufactured" (Askin \& Mol, 2018; Peterson, 1997). Irreplaceable artifacts, including listed buildings, may be deemed authentic because they are unique (see Hatch \& Schultz, 2017) or because they are typical, i.e., 
construed as particularly good representations of an established category (Carroll \& Swaminathan, 2000; Kovács, Carroll \& Lehman, 2013; Peterson, 1997). Our findings suggest that conceptions of authenticity expanded over time, rather than shifted, a development that paved the way for actors to draw on both uniqueness and typicality to authenticate an artifact. Uniqueness and typicality also manifested in the three authentication processes that we identified. Material Consolidation and Character Enhancement drew on uniqueness, the former through original building materials and the latter through verbal discourse, whereas Crafts Mobilization used typicality in the form of traditional production practices to establish authenticity. Regardless of the source of authenticity, irreplaceable artifacts gained their potency for institutional maintenance from authentication.

We propose authentication as a novel way in which artifacts interact with discourse to sustain institutions. In focusing on the qualities of artifacts that make them suitable for institutional maintenance, authentication starts from the selection of appropriate artifacts and then mobilizes practices and verbal discourse selectively to enhance the artifact's ability to consolidate the institution that it sustains. Adding to previous work, which suggested that artifacts stabilize institutions (Jones \& Massa, 2013; Lanzara \& Patriotta, 2007) or validate them (Patriotta et al., 2011), our work suggests that artifacts have different and malleable capacities for institutional maintenance that can be mobilized and enhanced through authentication, using materials, practices and verbal discourse in different combinations. As such, our study identifies authentication as a potent new form of institutional maintenance work.

We did not compare the respective institutional effects of the three forms of authentication but suggest that they may differ. Material Consolidation may be most likely to reinforce the institution as initially formulated because uniqueness (as a source of authenticity) was institutionalized before typicality in the domain of architectural heritage. Moreover, since materiality is less malleable than discourse, the potential for expanding authenticity is limited. 
In contrast, Character Enhancement may encourage institutional evolution and adaptation because immaterial expressions of authenticity are more malleable and open-ended than are material ones. The higher importance of verbal discourse in this form of authentication also enables more expansive accounts of authenticity than do the other forms of authentication. If we are right in suggesting that the three forms of authentication may differ in their institutional effects, actors may deliberately choose a form of authentication that constrains, respectively expands, the boundaries of the institution that they seek to maintain, i.e., facilitate institutional reproduction, respectively institutional evolution. Future research should examine systematically if the institutional effects of the three forms of authentication differ from one another, and under which circumstances each one is most effective. For instance, some forms of authentication may be more effective than others for sustaining specific institutions because they are deemed more appropriate in relation to that institution.

It is also plausible that the three identified forms of authentication may reinforce their respective effectiveness when used together. Actors may combine two or three types of authentication to open a wider spectrum for authentication, thereby enhancing the effectiveness of their institutional maintenance work. The combination of different forms of authentication may enable actors to mobilize divergent stakeholders to endorse their institutional maintenance work. Alternatively, the de-selection of a particular form of authentication may appeal to key stakeholders and thus be instrumental in some instances of institutional maintenance work. Future research could investigate the conditions under which a combination of two or three forms of authentication is more effective for institutional maintenance than is a single form.

\section{Boundary Conditions}

Our empirical study examined a particular institution, namely architectural heritage. This institution relies for its maintenance on irreplaceable artifacts in as much as the continued 
existence and functionality of listed buildings are essential for its survival. If listed buildings decay or otherwise lose their functionality for contemporary society, their ability to link the past to the present weakens and they lose their ability to effectively sustain the institution of architectural heritage. Rather, they may de facto contribute to its gradual erosion. However, delisted buildings could be mobilized as irreplaceable artifacts to sustain the institution of archaeological heritage (see Council of Europe, 1969) or become associated with other institutions that they then sustain.

Authentication applies, we argue, to all institutions that rely on irreplaceable artifacts for their maintenance. Such institutions include, most importantly, all heritage institutions that use irreplaceable artifacts to connect the past to the present, artifacts that are subject to decay and/or loss of functionality. An example is archaeological heritage. A spectacular example of an irreplaceable artifact in this domain is the prehistoric Lascaux cave in Dordogne, France. This cave was closed to the public in 1963 to protect its vivid prehistoric paintings and was subsequently re-opened to the public in an entirely rebuilt version that allows visitors to materially experience the cave even though that the original cave is closed off to visitors. Video footage from the original cave is made available to visitors to encourage them to partake in authenticating the replacement cave, and hence to sustain the institution of archaeological heritage. Another heritage institution that uses irreplaceable artifacts for its maintenance is that of religion. Buddhists go on pilgrimage to Sri Lanka to experience what are supposedly the original imprints of Buddha's foot and of his tooth. Christians pilgrimage to the Turin Cathedral in Italy to approach the Shroud of Turin, which supposedly is the original burial cloth of Jesus Christ. Similarly, Jews travel to Jerusalem on pilgrimage to touch the Wailing Wall, a remnant of the Temple Mount that was destroyed by the Romans in $70 \mathrm{CE}$. The existence of these original artifacts is crucially important for the institutional maintenance of religion; they cannot 
simply be replaced with reproductions without significantly diminishing their effectiveness for institutional maintenance.

Authentication applies to irreplaceable artifacts not only from the past but also from the present. Artifacts may be irreplaceable because they are regarded as unique representations of an individual or organization with cult status in a particular institutionalized domain. For instance, Elon Musk's first Tesla car could be qualified as an irreplaceable artifact that sustains the emerging institution of celebrity entrepreneurship. Contemporary artifacts may also, occasionally, be irreplaceable because they constitute an extraordinary exemplar of a particular institution. An example could be the world's biggest superyacht ever built, which sustains the institution of leisurely boat travel, or a Star Wars item from the film set, supporting the institution of pop culture.

To a lesser degree, authentication may also apply to replaceable artifacts, such as those used to maintain the institutions of public education or traffic regulation. For instance, school desks and traffic signs must conform to certain design specifications that pertain to those categories in order for them to sustain the institution of public education, respectively of traffic regulation. Easy chairs in schools and handwritten traffic signs on the road would hardly fit established design specifications. Authentication may determine the limits for the design of replaceable artifacts that carry a mandate of institutional maintenance, and hence play a role in maintaining a broader range of institutions than those relying on irreplaceable. Future research may investigate if our findings do indeed apply to institutions that rely on replaceable artifacts, i.e., institutions that require functional artifacts for their maintenance, but where their authenticity is not detrimental to their maintenance. Future research could investigate if, and under which conditions, authentication of an original artifact is more effective than its replacement for maintaining these kinds of institutions. 


\section{Concluding Remarks}

The articulation of authentication as a potent resource for institutional maintenance work enriches research at the interface of institutional work and authenticity. This work has implications also for society at large. The maintenance of architectural heritage - and other cultural institutions - represents our national and cultural identities, a topic that is increasingly significant in the context of increased globalization. Authentication can help us protect our collective identities, and shape their development, in a deliberate and reflexive manner, using irreplaceable artifacts as a creative starting point.

\section{REFERENCES}

Askin A., \& Mol J. (2018). 'Institutionalizing Authenticity in the Digitized World of Music'. Research in the Sociology of Organizations, 55: 159-202.

Barin Cruz, L., Aguilar Delgado, N., Leca, B., \& Gond, J.-P. (2016). 'Institutional Resilience in Extreme operating environments: the role of Institutional Work'. Business \& Society, 55(7): 970:1016.

Benjamin, W. (1968 [1935]). 'The work of art in the age of mechanical reproduction'. In H. Arendt (Ed.), Illuminations: Essays and reflections (pp. 214-218). London: Fontana.

Bitektine, A., \& Haack, P. (2015). "The "macro" and the "micro" of legitimacy: toward a multilevel theory of the legitimacy process'. Academy of Management Review, 40(1): 4975.

Blanc, A., \& Huault, I. (2014). 'Against the digital revolution? Institutional maintenance and artefacts within the French recorded music industry'. Technological Forecasting and Social Change, 83: 10-23. 
T0656

Boltanski, L. \& Thévenot, L. (2006 [1991]). On Justification: Economies of Worth. Princeton, NJ: Princeton University Press.

Boxenbaum, E., Huault, I., \& Leca, B. (2016). 'Le tournant “matériel” dans la théorie néoinstitutionnaliste'. In F.-X. de Vaujany, A. Hussenot, J.-F. Chanlat (Eds.), Théories des organisations: nouveaux tournants: 227-238. Paris: Economica.

Brand, S. (1995). How building learn: what happens after they're built. London: Penguin Books.

Carlile, P.R., Nicolini, D., Langley, A., \& Tsoukas, H. (2013). How Matter Matters: objects, artifacts and materiality in organization studies. Oxford: Oxford University Press.

Carroll, G.R. (2015). 'Authenticity: attribution, value and meaning'. In R.A. Scott, S.M. Kosslyn \& N. Pinkerton (Eds.), Emerging Trends in the Social and Behavioral Sciences: 1-13. Wiley Online Library.

Carroll, G.R., \& Swaminathan, A. (2000). 'Why the microbrewery movement? Organizational dynamics of resource partitioning in the U.S. brewing industry'. American Journal of Sociology, 106(3): 715-762.

Carroll, G.R., \& Wheaton, D.R. (2009). 'The organizational construction of authenticity: an examination of contemporary food and dining in the U.S.'. Research in Organizational Behavior, 29: 255-282.

Charmaz, K., \& Olesen, V. (1997). 'Ethnographic research in medical sociology'. Sociological Methods and Research, 25(4): 452-494.

Colombero, S. (2015). Instantiating through collective bricolage: the case of the Listed Buildings Institution. Ph.D. Thesis 2015ENMP0033. Mines ParisTech: Paris \& CBS: Copenhagen.

Corley, K.G., \& Gioia, D.A. (2004). 'Identity ambiguity and change in the wake of a corporate spin-off'. Administrative Science Quarterly, 49: 173-208. 
T0656

Council of Europe (1954). The European Cultural Convention. cf. https://www.coe.int/en/web/conventions/full-list/-/conventions/rms/090000168006457e . (1969). The European Convention on the Protection of the Archaeological Heritage. $c f$. https://www.coe.int/en/web/conventions/full-list/-/conventions/treaty/066

- (1975). The European Charter of the Architectural Heritage. cf. https://www.icomos.org/en/charters-and-texts/179-articles-en-

francais/ressources/charters-and-standards/170-european-charter-of-the-architectural$\underline{\text { heritage }}$

. (1985). The Grenada Convention. Convention for the Protection of the Architectural Heritage of Europe. $\quad c f$. https://www.coe.int/en/web/conventions/full-list//conventions/treaty/121 . (2005). The Faro Convention. Convention on the Value of Cultural Heritage for Society. $\quad c f . \quad$ https://www.coe.int/en/web/conventions/full-list//conventions/rms/0900001680083746

Creed, W.D., DeJordy, R., \& Lok, J. (2010). 'Being the change: Resolving institutional contradiction through identity work'. Academy of management journal, 53(6): 13361364.

Currie, G., Lockett, A., Finn, R., Martin, G., \& Waring, J. (2013). 'Institutional work to maintain professional power: recreating the model of medical professionalism'. Organization Studies, 33(7): 937-962.

Czarniawska, B., \& Joerges, B. (1996). 'Travels of ideas'. In B. Czarniawska \& G. Sevón (Eds.), Translating Organizational Change: 13-48. Berlin: Walter de Gruyter.

Czarniawska, B., \& Sevón, G. (1996). 'Introduction'. In B. Czarniawska \& G. Sevón (Eds.), Translating Organizational Change: 1-12. Berlin: Walter de Gruyter. 
T0656

Dacin, M.T., Munir, K., \& Tracey, P. (2010). 'Formal dining at Cambridge colleges: linking ritual performance and institutional maintenance'. Academy of Management Journal, 53(6): 1393-1418.

Denzin, N.K., \& Lincoln, Y.S. (2000). 'Introduction: the discipline and practice of qualitative research'. In N.K. Denzin \& Y.S. Lincoln (Eds.), Handbook of Qualitative Research (2 ${ }^{\text {nd }}$ Edition): 1-29. London, UK: Sage Publication.

Dover, G., \& Lawrence, T.B. (2010). 'Technology, institutions and entropy: understanding the critical and creative role of maintenance work'. In Technology and Organization 29: Essay in honour of Joan Woodward: 259-264.

Dutton, D. (2003). 'Authenticity in Art'. In J. Levinson (Ed.), The Oxford Handbook of Aesthetics: 258-274. Oxford University Press.

Eisenhardt, K.M., \& Graebner, M.E. (2007). 'Theory building from cases: opportunities and challenges'. Academy of Management Journal, 50(1): 25-32.

Esterberg, K.G. (2002). Qualitative methods in social research. Boston, MA: McGraw-Hill.

Eriksson, P., \& Kovalainen, A. (2008). Qualitative Methods in business research. London, UK: Sage Publications.

Gioia, D.A., Corley, K.G., \& Hamilton, A.L. (2013). 'Seeking qualitative rigor in inductive research: notes on the Gioia Methodology'. Organizational Research Methods, 16(1): $15-31$.

Glynn, M. A., \& Lounsbury, M. (2005). 'From the Critics' Corner: Logic Blending, Discursive Change and Authenticity in a Cultural Production System'. Journal of Management Studies, 42(5): 1031-1055.

Gold, R. (1969). 'Roles in sociological field observation'. In G. McCall \& J. Simmons (Eds.), Issues in participant observation: a text and reader. London, UK: Addison Wesley. 
T0656

Grayson, K., \& Martinec, R. (2004). 'Consumer perceptions of iconicity and indexicality and their influence on assessments of authentic market offerings'. Journal of Consumer Research, 31: 296-312.

Greenwood, R., Oliver, C., Lawrence T., \& Meyer, R.E. (2017). 'Introduction: into the Fourth Decade'. In R. Greenwood, C. Oliver, T. Lawrence \& R. E. Meyer (Eds.), The SAGE Handbook of Organizational Institutionalism (2nd Ed.): 1-24. London, UK: Sage Publications Ltd.

Hahn, O., \& Zuckerman, E.W. (2014). 'The denigration of heroes? How the status attainment process shapes attributions of considerateness and authenticity'. American Journal of Sociology, 120(2): 504-554.

Hatch, M.J., \& Schultz, M. (2017). 'Toward a theory of using history authentically: historicizing in the Carlsberg group'. Administrative Science Quarterly, 62(4): 657-697.

ICCROM (1931). The Athens Charter for the Restoration of Historic Monuments. cf. http://www.icomos.org/en/charters-and-texts/179-articles-en-

francais/ressources/charters-and-standards/167-the-athens-charter-for-the-restoration-

$\underline{\text { of-historic-monuments }}$ . (1964). The Venice Charter. The International Charter for the Conservation and Restauration of Monuments and Sites. $c f . \underline{\text { https://www.icomos.org/charters/venice_e.pdf }}$ ICOMOS (1994). Nara Charter. The Nara Document on Authenticity. cf. https://www.icomos.org/charters/nara-e.pdf - (2003). Principles for the Analysis, Conservation and Structural Restoration of Architectural Heritage. $c f$. https://www.icomos.org/charters/structures_e.pdf

- (2008). The Quebec Declaration of Spirit of Place. cf. https://whc.unesco.org/uploads/activities/documents/activity-646-2.pdf 
. (2014a). The Florence Declaration on Heritage and Landscape as Human Values. $c f$. https://www.icomos.org/images/DOCUMENTS/Secretariat/2015/GA_2014_results/GA

\section{4_Symposium_FlorenceDeclaration_EN_final_20150318.pdf}

- (2014b). Nara +20: On Heritage practices, cultural values and the concept of Authenticity. $c f$. http://www.japan-icomos.org/pdf/nara20_final_eng.pdf

Jokilehto, J. (1986). A history of Architectural Conservation. Institute of advanced architectural studies Ph.D. Thesis: University of York, UK.

Jones, C., Boxenbaum, E., \& Anthony, C. (2013). 'The immateriality of the material institutional logics'. Research in the Sociology of Organizations, 39A: 51-75.

Jones, C., Maoret, M., Massa, F.G., \& Svejenova, S. (2012). 'Rebels with a cause: formation, contestation and expansion of the de Novo category "Modern Architecture" (18701975)'. Organization Science, 23: 1523-1545.

Jones, C., \& Massa, F.G. (2013). 'From novel practice to consecrated exemplar: Unity Temple as a case of institutional evangelizing'. Organization Studies, 34: 1099-1136.

Justesen, L. \& Mik-Meyer, N. (2012). Qualitative research methods in organization studies (1 $1^{\text {st }}$ Edition). Copenhagen: Hans Reitzels Forlag.

Kovács, B., Carroll, G.R., \& Lehman, D.W. (2013). 'Authenticity and consumer value ratings: empirical tests from the Restaurant domain'. Organization Science, 25(2): 458-478.

Kvale, S. (1996). InterViews: an introduction to qualitative research interviewing. Thousand Oaks, CA: Sage Publications.

Lanzara, G.F., \& Patriotta, G. (2007). 'The institutionalization of knowledge in an automotive factory: templates, inscriptions and the problem of durability'. Organization Studies, 28(5): 635-660.

Lawrence, T. B., Suddaby, R., \& Leca, B. (2009). 'Introduction: Theorizing and studying institutional work'. In T. B. Lawrence, R. Suddaby, \& B. Leca (Eds.), Institutional work: 
Actors and agency in institutional studies of organizations: 1-27. Cambridge, UK: Cambridge University Press.

Lawrence, T.B., Leca, B., \& Zilber, T.B. (2013). 'Institutional Work: current research, new directions and overlooked issues'. Organization Studies, 34(8): 1023-1033.

Lawrence, T.B., \& Suddaby, R. (2006). 'Institutions and Institutional work'. In S.R. Clegg, C. Hardy, T.B. Lawrence \& W.R. Nord ( $2^{\text {nd }}$ Ed.), The Sage Handbook of Organization Studies: 215-254. London: Sage Publications Ltd.

Leca, B., \& Naccache, P. (2006). 'A critical realist approach to institutional entrepreneurship'. Organization, 13(5): 627-665.

Lehman, D.W., O’Connor, K., Kovács, B., \& Newman, G.E. (in press). 'Authenticity'. Academy of Management Annals.

MacCannell, D. (1973). 'Staged Authenticity: arrangements of social space in tourist settings'. American Journal of Sociology, 79(3): 589-603.

Martel, Y. (2001). Life of Pi. Knopf Canada.

Micelotta, E.R., \& Washington, M. (2013). 'Institutions and maintenance: The repair work of Italian professions'. Organization Studies, 34(8): 1137-1170.

Miles, M.B., \& Huberman, M.A. (1994). Qualitative data analysis: an expanded sourcebook ( $2^{\text {nd }}$ Edition). Thousand Oaks, CA: Sage Publications.

Monteiro, P., \& Nicolini, D. (2014). 'Recovering materiality in institutional work: prizes as an assemblage of human of material entities'. Journal of Management Inquiry: 1-21.

Nilsson, W. (2015). 'Positive institutional work: Exploring institutional work through the lens of positive organizational scholarship'. Academy of Management Review, 40(3): 370-398.

Norberg-Schulz, C. (1980). Genius Loci. Towards a phenomenology of architecture. New York: Rizzoli International Publications. 
T0656

Patriotta, G., Gond, J.P., \& Schultz, F. (2011). 'Controversies, orders of worth, and public justifications'. Journal of Management Studies, 48(8): 1804-1836.

Pendlebury, J., Short, M., \& While, A. (2009). 'Urban World Heritage Sites and the problem of authenticity'. Cities, 26(6): 349-358.

Pérouse de Montclos, J.-M. (1972). Architecture, description et vocabulaire méthodique. Paris: Éditions du Patrimoine / CMN.

Peterson, R.A. (1997). Creating country music: fabricating authenticity. Chicago: University of Chicago Press.

—. (2005). 'In search of Authenticity'. Journal of Management Studies: 42(5): 1083-1098.

Pinch, T. (2008). 'Technology and institutions: living in a material world'. Theory and Society, 37(5): 461-483.

Polanyi, M. (1966). The Tacit Dimension. London, UK: Routledge \& Kegan Paul.

Quinet, E. (1883). Viollet-le-Duc: Les églises de Paris. Paris: C. Marpon \& E. Flammarion.

Quinn-Trank, C. \& Washington, M. (2009). 'Maintaining an institution in a contested organizational field: the work of the AACSB and its constituents'. In T.B. Lawrence, R. Suddaby \& B. Leca (Eds.), Institutional work: actors and agency in institutional studies of organizations: 236-261. Cambridge, UK: Cambridge University Press.

Rafaeli, A. \& Vilnai-Yavetz, I. (2004). 'Emotion as connection of physical artifacts and organizations'. Organization Science, 15: 671-686.

Rao, H., Monin, P., \& Durand, R. (2005). 'Border crossing: bricolage and the erosion of categorical boundaries in French gastronomy'. American Sociological Review, 70(6): 968-991.

Raviola, E., \& Norbäck, M. (2013). 'Bringing technology and meaning into institutional work: making news at an Italian business newspaper'. Organization Studies, 34: 1171-1194. 
Rifaioglu, M.N., \& Sahin Güçan, N. (2008). 'Understanding and preserving spirit of place by an integrated methodology in historical urban contexts'. In: 16th ICOMOS General Assembly and International Symposium: 'Finding the spirit of place - between the tangible and the intangible', Sept. 29 - Oct. 4 2008, Quebec, Canada.

Robin, C. (2003). 'Conrad et Marcel Schlumberger: une aventure industrielle originale'. Bulletin de la Sabix, 34: 5-14.

Roubaudi, L., \& Jorion, T. (2014). Molitor: ceci n'est pas une piscine. Paris: Archibooks.

Rouillard, D. (2006). Architectures contemporaines et monuments historiques: guide des réalisations en France depuis 1980. Paris: Éditions Le Moniteur.

Siemsen, J. (1997). Sølvgades Skole 150 år i 1997: tekster og billeder omkring skolen der aldrip gi'r op - isar fra de sidste 50 år. København: Sølvgades Skole Publications.

Sillince, J.A.A., \& Barker, J.R. (2012). 'A tropological theory of institutionalization'. Organization Studies, 33(1): 7-38.

Sire, M.A. (2005). La France du Patrimoine: les choix de la mémoire. Paris: Gallimard \& Éditions du Patrimoine.

Smets, M. \& Jarzabkowski, P. (2013). 'Reconstructing institutional complexity in practice: A relational model of institutional work and complexity'. Human Relations, 66(10): 12791309.

Smith, L. (2006). Uses of heritage. New York: Routledge.

Strauss, A.L. (1987). Qualitative analysis for social scientists. New York: Cambridge University Press.

Suárez, D., \& Bromley, P. (2016). 'Institutional theories and levels of analysis: history, diffusion and translation'. In J. Schrwiewer (Ed.), World culture re-contextualised: 139159. Routledge/Taylor and Francis. 
T0656

Suchman, M.C. (1995). 'Managing legitimacy: strategic and institutional approaches'. Academy of Management Review, 20(3): 571-610.

_. (2003). 'The contract as social artifact'. Law \& Society Review, 37: 91-142.

UNESCO (1972). World Heritage Convention Concerning the Protection of the World Cultural and Natural Heritage. $c f$. https://whc.unesco.org/archive/convention-en.pdf

- (1977). Operational Guidelines for the Implementation of the World Heritage Convention 1.cf. http://whc.unesco.org/archivelout/opgu77.htm

van Balen, K. (2008). 'The Nara Grid: An evaluation scheme based on the Nara Document on Authenticity'. APT Bulletin, 39(2/3): 39-45.

Viollet-le-Duc, E. (1863). Entretiens sur l'Architecture. Collection Archigraphy. Suisse: Infolio.

Yin, R.K. (2013). Case study research: design and methods ( $5^{\text {th }}$ Edition). London, UK: Sage Publications.

Zilber, T.B. (2009). 'Institutional maintenance as narratives acts'. In T.B. Lawrence, R. Suddaby \& B. Leca (Eds.), Institutional work: actors and agency in institutional studies of organizations: 205-235. Cambridge, UK: Cambridge University Press.

. (2011). 'Institutional multiplicity in practice: a tale of two high-tech conferences in Israel'. Organization Science, 22(6): 1539-1559.

Zucker, L.G. (1988). 'Where do institutional patterns come from? Organizations as actors in social systems'. In L.G. Zucker (Ed.), Institutional patterns and organizations: culture and environment: 23-52. Cambridge, MA: Ballinger. 
Table I. The type of the selected listed buildings

\begin{tabular}{|c|c|c|c|}
\hline $\begin{array}{l}\text { Name of the } \\
\text { Building }\end{array}$ & $\begin{array}{l}\text { Date of } \\
\text { Construction }\end{array}$ & \begin{tabular}{|l|} 
Date of \\
Modernization
\end{tabular} & Reasons of the contemporary adjustments \\
\hline Nyboder (DK) & 1631 & $2011-2014$ & $\begin{array}{l}\text { Built by King Christian IV, Nyboder underwent } \\
\text { renovation between } 2011 \text { and } 2014 \text { to allow } \\
\text { students of the Danish army to keep living there. } \\
\text { These famous yellow houses represent a unique } \\
\text { residential area of Denmark, which inspire many } \\
\text { urban architects over the years. }\end{array}$ \\
\hline $\begin{array}{l}\text { French } \\
\text { Pantheon (FR) }\end{array}$ & 1790 & $2013-2015$ & $\begin{array}{l}\text { Old church built in } 1790 \text { by the architects } \\
\text { Soufflot and Rondelet, it is used as a cenotaph } \\
\text { dedicated to the French Grands Hommes that } \\
\text { promoted the Republic. The Pantheon } \\
\text { incessantly undergoes restoration. This study } \\
\text { focuses on recent renovation of the Dome and its } \\
\text { upper Lantern, mainly to avoid stones to fall. }\end{array}$ \\
\hline $\begin{array}{l}\text { Sølvgade Skole } \\
\text { (DK) }\end{array}$ & 1847 & 2012 & $\begin{array}{l}\text { The main objective of the renovation of the } \\
\text { Denmark's oldest primary school was to create a } \\
\text { new extension for extracurricular activities in } \\
\text { order to answer new teaching demands. }\end{array}$ \\
\hline $\begin{array}{l}\text { École des } \\
\text { Mines de Paris } \\
\text { (FR) }\end{array}$ & 1707 & $2014-2015$ & $\begin{array}{l}\text { The current renovation concerns the } \\
\text { Schlumberger Lecture Hall that is considered } \\
\text { obsolete for teaching purposes. It is names after } \\
\text { a prestigious engineer who reflects the high and } \\
\text { worldwide reputation of the school. }\end{array}$ \\
\hline $\begin{array}{l}\text { Munkegård } \\
\text { Skole (DK) }\end{array}$ & $1954-1955$ & 2005 & $\begin{array}{l}\text { This school building was constructed by the } \\
\text { Danish architect Arne Jacobsen. To restore and } \\
\text { extend the school, which remains one of the most } \\
\text { famous Danish modern buildings, } \\
\text { contemporary architects used Jacobsen's old } \\
\text { detailed drawings to bring back some missing } \\
\text { details. }\end{array}$ \\
\hline $\begin{array}{l}\text { Molitor } \\
\text { Swimming pool } \\
\text { (FR) }\end{array}$ & 1929 & $2007-2014$ & $\begin{array}{l}\text { This Art Deco swimming pool underwent } \\
\text { renovation after it had become a popular street- } \\
\text { art spot in the late } 1980 \text { s. The building re-opened } \\
\text { as a luxurious swimming pool in May 2014, } \\
\text { reproducing entertaining features as they were in } \\
\text { the 1930s. The bikini was legendary imagined } \\
\text { and first used there. }\end{array}$ \\
\hline
\end{tabular}


Table II. The list of interviewees

\begin{tabular}{|l|l|l|}
\hline Interviewee's status & Building & Length \\
\hline Architect 1 & Nyboder & $1 \mathrm{~h} 18 \mathrm{~min}$ \\
\hline Lead Architect 1 & Nyboder & $1 \mathrm{~h} 07 \mathrm{~min}$ \\
\hline Client 1 & Nyboder & $1 \mathrm{~h} 14 \mathrm{~min}$ \\
\hline Client 2 & Nyboder & $45 \mathrm{~min}$ \\
\hline Patron/Sponsor 1 & Nyboder & $1 \mathrm{~h} 26 \mathrm{~min}$ \\
\hline Lead Architect 2 & Sølvgade Skole & $48 \mathrm{~min}$ \\
\hline Lead Architect 3 & Munkegård Skole & $55 \mathrm{~min}$ \\
\hline Client 3 & Munkegård Skole & $1 \mathrm{~h} 22 \mathrm{~min}$ \\
\hline Pr. of Education History 1 & $\begin{array}{l}\text { Sølvgade + Munkegård } \\
\text { Skolen }\end{array}$ & $1 \mathrm{~h} 06 \mathrm{~min}$ \\
\hline CPO Architect 1 & All Danish buildings & $1 \mathrm{~h} 12 \mathrm{~min}$ \\
\hline Lead Architect 4 & French Pantheon & $1 \mathrm{~h} 04 \mathrm{~min}$ \\
\hline CPO Architect 2 + Client 4 & French Pantheon & $2 \mathrm{~h} 33 \mathrm{~min}$ \\
\hline Client 5 & École des Mines de Paris & $55 \mathrm{~min}$ \\
\hline Architect 2 & École des Mines de Paris & $1 \mathrm{~h} 56 \mathrm{~min}$ \\
\hline Lead Architect 5 & Molitor & $49 \mathrm{~min}$ \\
\hline Client 6 & Molitor & $1 \mathrm{~h} 09 \mathrm{~min}$ \\
\hline Patron/Sponsor 2 & All French buildings & $1 \mathrm{~h} 26 \mathrm{~min}$ \\
\hline $\begin{array}{l}\text { Head of one Protection Society } \\
\text { 1 Pr. of Art History 1 }\end{array}$ & All French buildings & $1 \mathrm{~h} 10 \mathrm{~min}$ \\
\hline CPO Architect 3 & All French buildings & $1 \mathrm{~h} 14 \mathrm{~min}$ \\
\hline CPO Architect 4 & All French buildings & $1 \mathrm{~h} 50 \mathrm{~min}$ \\
\hline Archaeologist 1 & All French buildings & $1 \mathrm{~h} 49 \mathrm{~min}$ \\
\hline Former ICOMOS member 1 & All French buildings & $1 \mathrm{~h} 57 \mathrm{~min}$ \\
\hline Architect 3 & All buildings & $1 \mathrm{~h} 13 \mathrm{~min}$ \\
\hline $\begin{array}{l}\text { Head of one Protection Society } \\
2\end{array}$ & All buildings & $1 \mathrm{~h} 40 \mathrm{~min}$ \\
\hline
\end{tabular}


Table III. Data table

\begin{tabular}{|c|c|}
\hline 2nd order themes & Selected quotes on 1 st order codes \\
\hline \multirow[b]{2}{*}{ Form \& Design } & Keeping intact the both internal and external building's structure \\
\hline & $\begin{array}{l}\text { "There is a lot of differences inside as all of the older houses parts were different, but still, } \\
\text { we kept the original buildings' structures. Also, you have [outside] this very obvious rows' } \\
\text { rhythm; and that is a value we have to protect" (Client 1) } \\
\text { "The addition does not touch the wall, it does not touch the ceiling, and it is just put on the } \\
\text { floor so, in principle, you can take it apart and carrying out and then out what we have the } \\
\text { original room intact again" (Client 3) }\end{array}$ \\
\hline \multirow{4}{*}{ Materials \& Substance } & Re-using original material components of the building \\
\hline & $\begin{array}{l}\text { "We reused the door. We found them out there ... before we take out one door, we give it a } \\
\text { number, and labeled it on the plan ... and it was kept in storage and then when we have done } \\
\text { the insulation and built up the floor and the ceiling and everything, we take that specific door } \\
\text { back on these hinges again. And that is sustainable because you reused the material" (Client } \\
\text { 2) } \\
\text { "For this kind of building, sorry if I repeat, but what it is absolutely awesome is because of } \\
\text { the quality of the original structure and architecture, one of the goal is not to change the } \\
\text { original material elements; otherwise it would go against the interest of the building itself" } \\
\text { (CPO Architect 2) }\end{array}$ \\
\hline & Enabling the reversibility of added elements \\
\hline & $\begin{array}{l}\text { "But when we put this furniture here, this is a new furniture indeed, we see clearly what is } \\
\text { new and what is old. The [Cultural Protection Office] said "as long as you can remove this } \\
\text { furniture, it is ok"! If we had built it like a stationary thing, we they do not allowed it. Here } \\
\text { they said: "You can remove it, and that is OK" (Client 3) } \\
\text { "These circles are completely reversible, as they are outside the building. If my successors } \\
\text { find that I have done something wrong or that a better and finer process is found, they will be } \\
\text { able to remove them extremely easily. So that is what we name the notion of reversibility" } \\
\text { (Lead Architect 4) }\end{array}$ \\
\hline \multirow{4}{*}{ Location \& Setting } & Introducing the building as part of the neighborhood \\
\hline & $\begin{array}{l}\text { "We need to return to Caesar what belongs to Caesar; it is the city of Paris which had the } \\
\text { courage to launch a call for bid without overwhelming the common people with public } \\
\text { considerations. The reason was mainly that Paris did not wish to invest public or State money } \\
\text { in a swimming-pool in the 16th arrondissement" (Client 6) } \\
\text { "I really love it! I think it is fit well with the urban fabric, I think it is great cause normally if } \\
\text { you make a .., I mean I was very worry about doing this because quite frankly, it is a very } \\
\text { historical area and it's very rare that you get a big job like that so close to the center. So for } \\
\text { this reason, I am very pleased that I can look at it with good pride and I think we did a good } \\
\text { job, a lot of people like it and there is photographer living in the street who had been sending } \\
\text { me emails about how he loves hanging around and photographing this building on night and } \\
\text { special ... you know!" (Lead Architect 2) }\end{array}$ \\
\hline & Choosing new materials to fit with building location \\
\hline & $\begin{array}{l}\text { "Because they were not allowed to do anything at the old existing school, the project was to } \\
\text { create an underground space as they have a very big need for modern rooms because all the } \\
\text { rooms there were small rooms" (Pr. of Education History 1) }\end{array}$ \\
\hline
\end{tabular}




\begin{tabular}{|c|c|}
\hline & $\begin{array}{l}\text { "Why did we not remake iron as original and replace it with new stainless material? Actually } \\
\text { we could while buying it from some eco-museums in England but construction works } \\
\text { constraints were strong and there is a time when decisions have to been made, especially } \\
\text { when it is expensive" (Lead Architect 4) }\end{array}$ \\
\hline \multirow{6}{*}{$\begin{array}{l}\text { Tradition \& } \\
\text { Technique }\end{array}$} & Using original construction techniques to reproduce (removed) material elements \\
\hline & $\begin{array}{l}\text { "Because we are really focused on the materials, the original materials, the authenticity, } \\
\text { we used the same materials and methods and so on. So you could compare it more to } \\
\text { conservation ... yeah ... conservation technics where you sort of stop the decay and you } \\
\text { preserve what is there with the same kind of materials ... So, that you, sort of speaking, have } \\
\text { an original thing still" (Patron 1) } \\
\text { "... for us we only give value if the brick used, it is made the same way as the original brick } \\
\text { and used the same way as the original brick and has the same pattern as the original ... So for } \\
\text { us, for instance, putting a machine brick, a machine made at that point would not give any } \\
\text { value" (Lead Architect 1) }\end{array}$ \\
\hline & Adding new building elements that resemble the original ones \\
\hline & $\begin{array}{l}\text { "If you know exactly how the original doors looked, it would be natural to give the new doors } \\
\text { the same shape, because, you know ... you get this historical feeling of the room when you } \\
\text { step in" (CPO Architect 1) } \\
\text { "Egyptian decorations and the original stage and curtain were redone, they also found an } \\
\text { original armchair in the basement so they redid all the chairs with the same look with the } \\
\text { small beetle above because it symbolized what they wanted to respect" (Pr. of Art History 1) }\end{array}$ \\
\hline & Using modern technologies to enhance building program \\
\hline & $\begin{array}{l}\text { "Thanks to new technologies, technical improvements of the existing structure. All the } \\
\text { glasses have been changed: now there is a two layered-structure with gas in between before } \\
\text { it was just one layer glass!" (Lead Architect 3) } \\
\text { "Some materials are good, I mean, for example the fact that you have Wi-Fi: it is perfect for } \\
\text { listed buildings; you do not have to put all these cold lines into the building. So there is a lot } \\
\text { of good things with a new technology" (Patron 2) }\end{array}$ \\
\hline \multirow{4}{*}{ Spirit \& Feeling } & Adding new building elements to showcase the building's main features \\
\hline & $\begin{array}{l}\text { "We had to use the } 16 \text { same colors to do it in the spirit of Arne Jacobsen. So we have these } \\
\text { sketches, we have these proposal every time and every time we have a discussion with the } \\
\text { CPO in order to allow them" (Lead Architect } 3 \text { ) } \\
\text { "The first big artistic intervention at Molitor was made during the building works by Futura } \\
2000 \text {, nicknamed the "Godfather of Graffiti". When Futura sells a canvas, it is between } 20 \mathrm{k} \\
\text { and } 100 \mathrm{k} \text { euros. We called him and told him the Molitor underground story, what we wanted } \\
\text { to do here, i.e., the ultra- open and creative living space, etc. He just said "Banco!" [...] So } \\
\text { he came and left a } 25 \text {-meter fresco" (Client } 6 \text { ) }\end{array}$ \\
\hline & Highlighting symbolic relations between building and national history \\
\hline & $\begin{array}{l}\text { "And basically when we started the modernization, people said we need to secure the } \\
\text { historical and architectural value. Nyboder, whatever you make a cannon of culture in } \\
\text { Denmark, concerning the historical buildings, Nyboder is always part of it. It has been owned } \\
\text { by the Military for almost } 400 \text { years; so in Denmark it is an iconic building. We have the } \\
\text { church, the dome in Roskilde, Nyboder, etc. But this is also part of it, so nationally is very } \\
\text { important" (Architect 1) } \\
\text { "Sølvgade ... it is the oldest Danish elementary school which is still working. That is probably } \\
\text { true. I mean, there are others in Denmark but they are not schools anymore. So that is probably } \\
\text { what makes it interesting, it is that it is still functioning as a school ... so it is probably true } \\
\text { that it is the oldest!" (Lead Architect 2) }\end{array}$ \\
\hline Use \& Function & Avoiding the transformation into a museum \\
\hline
\end{tabular}


"There is no interest in transforming listed buildings into museums. Again, we do not want a listed building to become a museum: we want them to live; we want them to be able to be part of everyday life!" (CPO Architect 1)

"From the moment they are disused or became a museum, it is just like very annoying because they are dead, they are mummified, there they are; we are in the state of mummification. And that is not the role of architecture!" (Architect 2)

\section{Keeping the same functionality of the building at the time of protection}

"The aim of our building program has been to preserve both the pool through its material building but also in its use. Here it remains an intellectual disposition vis-à-vis the monument because, as a building has a life, when the function is gone but the building matters, you have to keep the ruin since it is its death" (Lead Architect 5)

"We always have a discussion about what we called the Genius Loci; I mean, the soul of the house or the fairy dust of the house ... You know the engineers, they will shake ... they will know "the architects are crazy", but a philosopher would say "yes that is what it is all about", that the house sort of keeps its soul, keeps its narrative and brings it from the past into the future through the conservation of its function" (Patron 1) 
Figure 1: The listed buildings (all right reserved)

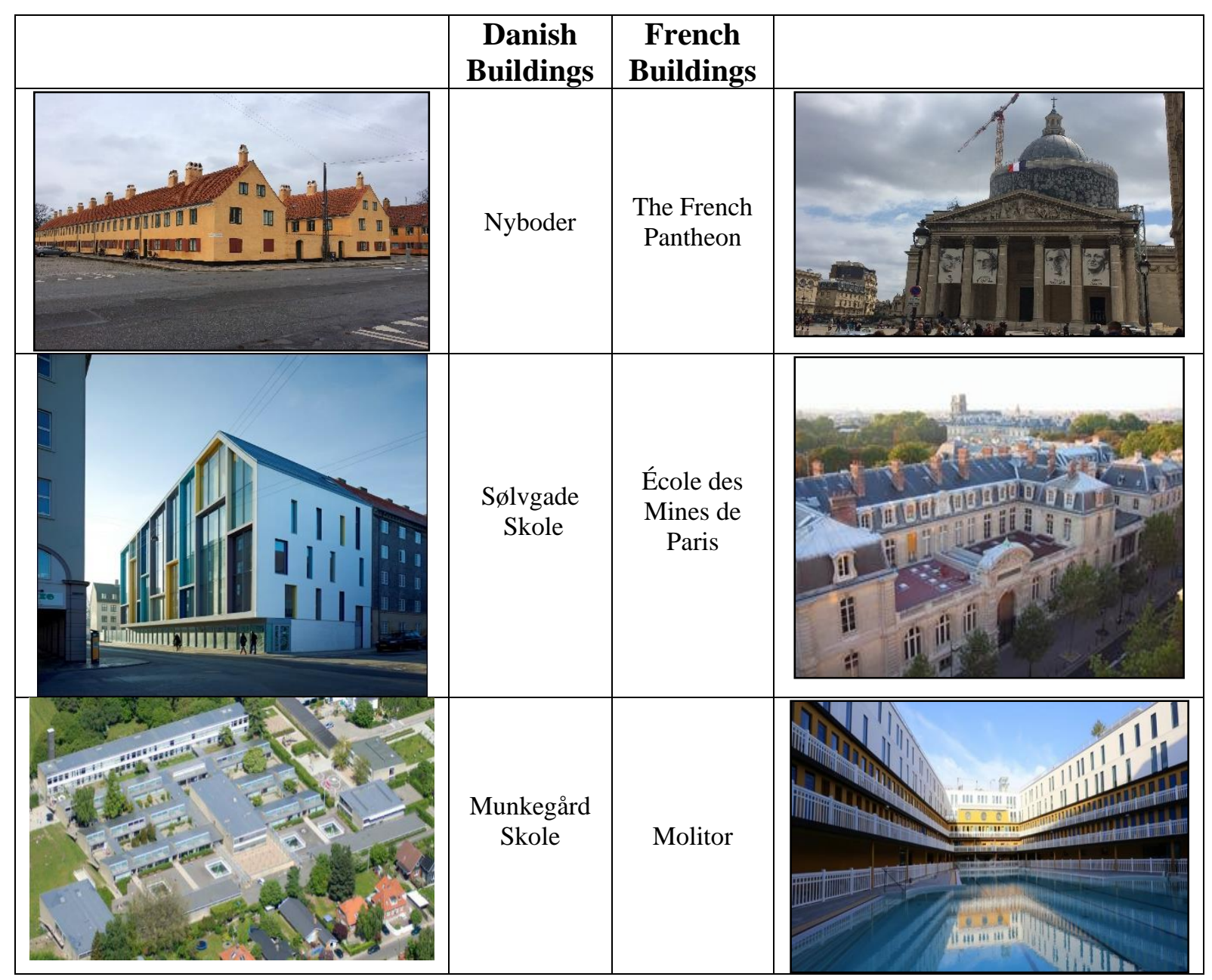


Figure 2. Data Structure

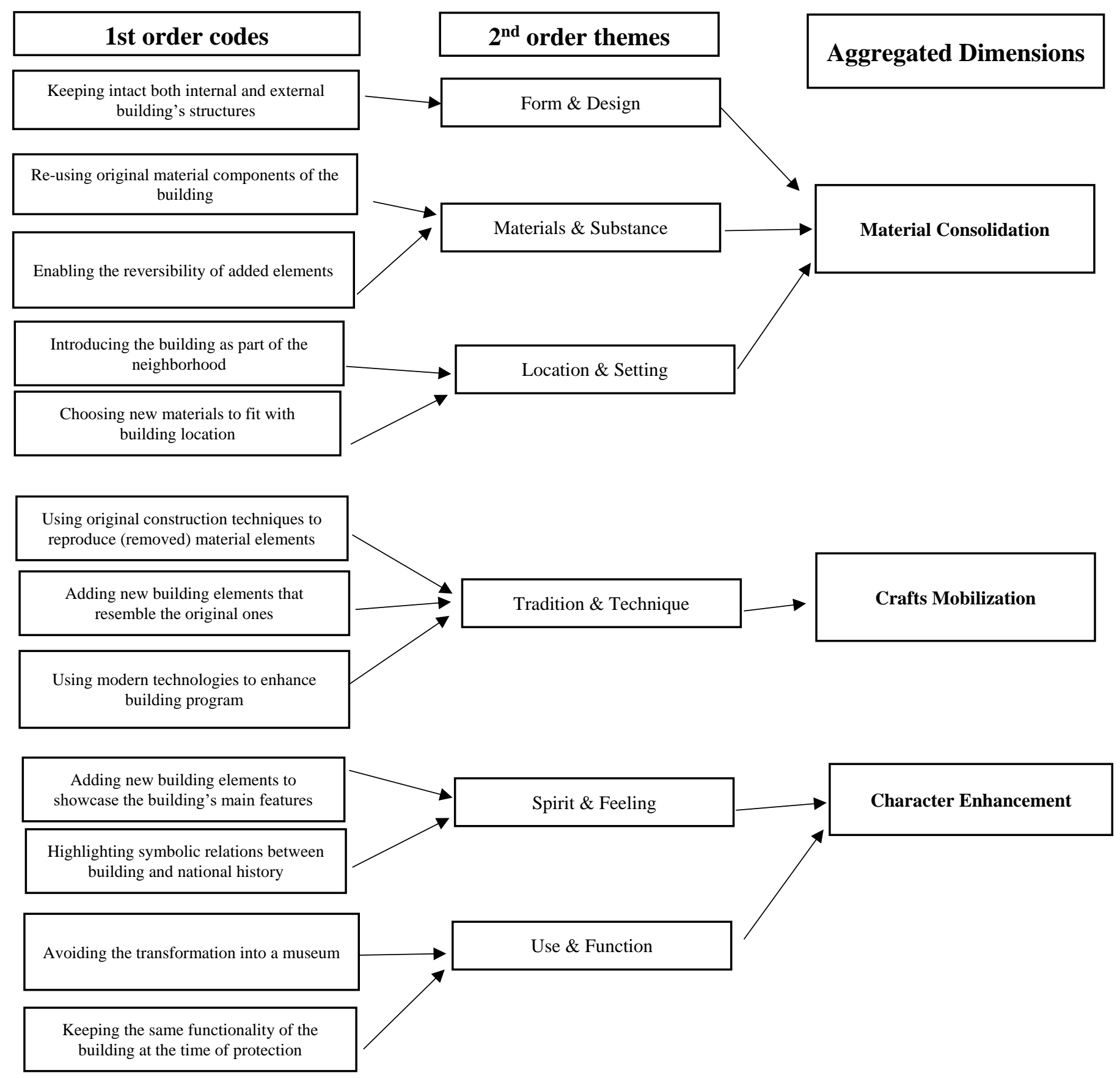

